\title{
Social Studies Teachers' Perception of Junior High School Social Studies Curriculum in Berekum Municipality
}

\author{
Collins Appiah \\ MPhil. Berekum College of Education. Ghana West Africa \\ Augustine Adjei \\ MPhil/M.Ed. Offinso College of Education. Ghana West Africa
}

\begin{abstract}
The study aimed at determining teachers' perception of Social Studies and how they teach the subject at Junior High Schools in Berekum Municipality of Brong Ahafo Region in Ghana. Four research questions guided the study: 1, what are the perceptions of Social Studies teachers about the nature of Social Studies? 2. What are the techniques employed by social studies teachers? 3. What is the nature and purpose of Social Studies curriculum at the Junior High School? 4. What is the significance of in-service training to the Social Studies teachers at the Junior High School? The main instrument used for the study was questionnaire. A questionnaire made up of forty (40) close-ended four-point Likert Scale Structured items were administered to hundred (100) Social Studies teachers in the selected twenty-five (25) Junior High Schools in Berekum Municipality. The questionnaire was divided into seven parts (A, B, C, D, E, F, \& G). Areas examined include Meaning of Social Studies, Academic and professional Qualification, Scope and Goals of Social Studies, nature of Social studies Education and Techniques of Teaching Social Studies. The sampling technique for the study was both purposive and random sampling. The data obtained from the questionnaire suggest that in all, most teachers were homogenous in their assertion that the nature of social studies is that of citizenship education. This is consistent with Banks (1990) that citizenship education is the primary focus of social studies in the school curriculum which promotes desirable participatory citizenship and further confirmed by the position of Bar and Shermis, (1977) that social studies is an integration of experience concerning human relations for the purpose of citizenship education. It was also concluded that the purpose of Social Studies is to develop positive attitudes, values and skills of pupils. It is recommended that teachers continue to acquire relevant knowledge on making Social Studies more relevant to the needs of the citizenry and abreast themselves with teaching techniques that would enhance practical ways of learning and encourage the application of real- life situation.
\end{abstract}

Keywords:JHS: Junior High School, MIT: Massachusetts Institute of Technology, CRDD; Curriculum Research and Development Division, NACC: National Association of the Curriculum and Courses, fCUBE: free Compulsory and Universal Basic Education

DOI: $10.7176 / \mathrm{JEP} / 12-11-03$

Publication date: April $30^{\text {th }} 2021$

\section{Background of the Study}

Social studies was adopted as a measure that would enable students to acquire skills needed to fit them in their environment. As a subject of study, social studies was introduced in the national curriculum between 1940 to 1946 in Teacher Training Colleges as an integrated area of study on experimental basis in Ghana but it was short lived due to the negative attitudes of teachers and students. It is important to note that by 1952 the single subject approach had taken over the integrated approach. This was due to the fact that social science graduates from the University of Ghana who were to teach social studies could not cope with the integrated approach as they had specialized in the single subjects (Tamakloe, 1988).

By 1965 integrated social studies had begun to gain momentum in Ghana. This was as a result of some graduates and non-graduates who were sent to Wales and Bristol to study the "Environmental Studies Approach" and the teaching of "integrated social studies." By 1971 many of them had returned to Ghana and were posted to the Teacher Training Colleges to spearhead the development of the integrated programme which they had studied abroad. The latter part of 1971 saw a general concern in the country over the structure and content of formal education which was viewed as too academic without the concern for the needs of the Ghanaian society. Consequently the Dzobo Committee (1972) was set up to overhaul the curriculum and make proposals for reforms. The committee among other recommendations emphasized the need for curriculum diversification that would be relevant to national needs and aspirations. In 1974, the then government issued a white paper on the proposals under the title 'the new structure and content of education for Ghana'

\section{Statement of the Problem}

There appears a difference between teachers' perception of Social Studies and how they teach the subject at the JHS in Berekum Municipality. This seems to have created a huge gap which is affecting the quality of teaching 
and learning of the subject at the Junior High Schools in Berekum. Quartey (2003), ever since Social Studies started to exist on the continent; it has never been understood in the correct way by some of its stakeholders. As a result, Social Studies, for different people, mean different things which serve as a hindrance in achieving its educational objectives like understanding, acquisition of skills and desirable attitudes and values which will help the learners solve personal and societal problems. It is upon these reasons I investigated into teachers' perception of Social Studies and how they teach the subject in the Junior High School in Berekum Municipality, in Brong Ahafo Region of Ghana.

\section{Purpose of the Study}

The purpose of the study was to examine Social Studies teachers' perception of the JHS social studies curriculum in Berekum Municipality. The study is to generate evidence on what is happening in the field, and also, take a critical look at how teachers approach the teaching of the subject.

\section{Objectives of the study}

The objective is to;

1. Explore Social Studies teachers' perception about the nature of Social Studies at the JHS.

2. Examine the effectiveness of the methods used by teachers in teaching social studies.

3. Examine the academic and professional competencies of Social Studies teachers at the Junior High School.

4. Examine the significance of in-service training in shaping Social Studies teachers perception of the discipline.

\section{Research Questions}

1. What are the perceptions of Social Studies teachers about the nature of social studies?

2. What are the techniques uses in teaching social studies at the Junior High School?

3. What are the academic and professional competencies of Social Studies teachers at the Junior High School?

4. What is the significance of in-service training in shaping social studies teachers' perception of the discipline?

\section{Significance of the Study}

The findings of the study are expected to be particularly relevant to educational policy and decision makers responsible for the development and improvement of social studies teaching in Junior High schools. This is because the result of the study will reveal the perception of social studies teachers as they exhibit in the classroom and this will help the Ghana Education Service (GES) to have a greater insight into the strengths and weakness of particular educational policies affecting the teaching and learning of social studies in the Berekum Municipality. It is also expected that the research will bring to light the defects of methods and strategies adopted by teachers of social studies. The findings would help Berekum Municipal Assembly in planning in-service training for teachers to upgrade their knowledge on the teaching of social studies. Finally, the findings would help improve quality education by serving as a reference source to those who wish to identify areas where support or materials are needed to enrich the social studies programme.

\section{Meaning of Social Studies}

Over the years there has not been consensus among Social Studies scholars as the term Social Studies means. Educators in the field give various answers to the question depending on their orientation and perception of the subject. No doubt the subject has had a turbulent history which culminated in a number of schools of thought. These schools of thought include social studies taught as an amalgamation of the social sciences, an approach as human relations and citizenship education (Ayaaba, 2011).

\section{Social studies taught as an amalgamation of the social sciences}

People of this persuasion believe that for young people to become reflective individuals, they need to acquire sound knowledge and skills of particular social science subjects. In this end, they propose definition such as the following;

1. Social studies is an interdisciplinary field of learning drawing upon the concepts and means of the social sciences and related areas (Dynneson \& Gross, 1999).

2. Social studies gain some of its identity from the social sciences such as History, Geography, Political science, anthropology, economics, sociology etc (Martorella, 1994).

3. Social studies includes much of the subject matter of History, Geography, Civic and Economics (Aggarwal, 2001) 


\section{Social Studies Taught as Human Relations}

There are other social studies educators who are of the views that good citizenship is contingent on the values, attitudes and behaviours that one exhibits towards others in the society. To these, therefore, social studies teaches the youth how to live responsibly in society by inculcating in them desirable democratic values and attitudes such as honesty, respect for oneself and others, tolerance of divergent views, hard work and discipline. Proponents of this school of thought advance definitions of social studies such as the following:

1. Social studies is an integration of experience and knowledge concerning human relations for the purpose of citizenship education (Bar, Barth, \& Shermis, 1977).

2. Social studies is primarily concerned with the study of human relationships believed to be the most important in developing responsible citizenship (Michaelis, 1988).

3. Social studies places premium on individual qualities such as patriotism,

honesty, diligence, obedience, and critical thinking, and also group ideals like interdependence, co-operation and peaceful co-existence (Tamakloe, 1994).

\section{Social Studies Taught as Method or Approach}

This school of thought upholds the view that social studies is a method or approach of teaching the social science disciplines. In the instructional setting, a method or an approach is a teacher's overall plan in a lesson delivery. It includes the advance preparation, selection of content to achieve the lesson objectives, the techniques used and activities carried out during the lesson as well as the procedures adopted to assess the effectiveness of the lesson delivery. To describe social studies as a method or an approach to the teaching of the social sciences simply connotes that it is not a subject on its own. Protagonists of this view give the following definitions among others: 1. Social studies are the social sciences simplified for pedagogical purposes (Wesley \& Wronski, 1964)

2. Social studies consists of adaptations of knowledge from the social sciences for teaching purposes at the primary and secondary levels of education (Thesaurus of ERIC.1987).

3. Social studies is an integrated interdisciplinary approach to the study of society and the environment (Junior Secondary School syllabus, Ghana.1987).

Social studies taught as citizenship education.

Proponents of this school of thought believe that social studies should prepare young people for adult citizenship roles. They contend that although all other subjects play a significant role in developing informed and responsible citizenship, it is only social studies that has citizenship development as its priority goal (Banks. 1990). To this end definitions of social studies include the following;

1. Social studies is the inter disciplinary integration of social science and humanities concepts for the purpose of practicing problem solving and decision making for developing citizenship skills on critical social issues (Barth,1993).

2. Social studies is the study of people. Social studies should help students acquire knowledge, master the processes of learning, and become active citizens (Zarrillo, 2000).

3. Social studies is the preparation of young people so that they possess the Knowledge, skills, and values necessary for active participation in society (Ross, 2006).

The lack of consensus on the definition of social studies seems to suggest that there are as many definitions of the subject as there as social studies educators. Nonetheless, to reconcile all these schools of thought and to give the subject a focus, the NCSS in 1992 adopted the following definition of social studies: social studies is the integrated study of the social sciences and humanities to promote civic competence. The primary purpose of social studies is to help young people to develop the ability to make informed and reasoned decisions for the public good as citizen of culturally diverse democratic societies in an interdependent world. It is important to note that, teachers' understanding of Social studies determine to how they teach.

\section{Social Studies Taught as Citizenship Education}

The educators of this school of thought uphold the view that Social Studies should prepare the young people for adult citizenship role. Hayford, (1992) citizenship education implies the acquisition of the necessary knowledge and skills needed for the promotion of democracy. The Social Studies draft syllabus of Ghana Education Service (2007) for Junior High and Senior High Schools is 'Citizenship education'. Banks (1985) stressed that Social studies is that of elementary and high school curriculum which has primary responsibility of helping students to develop the knowledge, skills, attitudes and values needed to participate in civic life of their local communities, nation and the world. While the other curriculum areas also help students to attain some of the skills needed to participate in the democratic society, Social Studies is the only curriculum which has the development of civic competence and skills as its primary goal. 


\section{The Scope of Social Studies}

The term "scope" had become popular in education circles after 1945. Developments between the two world wars led to the emergence of new pattern of selecting the content for social studies programme. Until quite recently the term "scope of social studies" had been shifting sand (Tamakloe, 1994). Curriculum expert are yet to agree on what the term, scope of social studies, is as it varies from writer too writer. Banks (1990) at the lower grade in school the scope of the subject is based on institutions and communities such as the home, family, the school, the neighborhood and the community. He goes on further, to say that at the higher level a variety of elective course such as sociology, psychology and problems of democracy are offered. In another development Martorella, (1994) writes that most educators would concede that social studies gain some of its identity from the social science, such as history, political science, geography, economics, sociology, anthropology and psychology. In explaining the scope of social studies GES, (2001) emphasizes that social studies take its source from geography; history, economics and civic education and integrates it in a fashion that creates a subjects of its own. Ravitch (2003) sums it up by saying, "social studies is seen as a broad umbrella that covers the range of subjects, disciplines, and skills". It is significant to note that when subject areas are used to define the scope of social studies, perhaps the objective is to promote understanding and values associated with the subject area.

Aggarwal, (1982) the scope of social studies should include a study of relationships, function study of natural science and arts and a study of current affairs. In keeping with this thematic nature, Tamakloe, (1991) writes that "the structure of the content selected for the teaching and learning process in social studies must be such that it cuts across discipline" (p.46). To him this can be possible if the content is thematic in nature. He added; "themes such as the school community, our local community, the national community our continent and other like citizenship, cooperation, interdependence and nationalism easily lend themselves to organization which relies heavily on the use of concepts, facts, skills and values from various discipline". It must be emphasized, however, that social studies and social science are distinct programmes. To achieve its overall goals social studies promotes learning experiences that have both distinct content focus and process focus. The latter for instance provide opportunities for learners to become actively involved with interpreting and judging knowledge. It could be inferred from the discussion that the scope of social studies is unlimited. It is in the light that Leming \& Ellington (2003) descried the scope of social studies as "boundless, eschewing substantive content and lacking focus for effective practice." They add, "Students rank social studies courses as one of their least liked subjects and social studies textbooks are largely superficial and vapid" (pp i-ii). Zevin (2000) in his 'personal prologue" writes that, " part of the reason social studies is dislikes by so many students is the ....arguments, knowledge of facts, names, places [and all] the facts they had to know" (p. xiv).

Perhaps the debate about the scope of social studies may be partly due to the nature of the subject. According to Tamakloe (1994) the boundless nature exhibited by the scope of social studies is the apparent results of the multiplicity of concepts, skills, knowledge, and values that can be utilized to explain issues, phenomena and solve any problem which faces society. Commenting on the nature of social studies Ross and Marker (2005) remarked that:

Social studies is the most inclusive of all subject and determining the boundaries of what is taught in social studies requires decision about what social knowledge is most important, which skills and behaviors' are most valuable, and what values are most significant. As a result, the field curriculum terrain is, has been, and will continue to be subject to debate (p. 139). It appears the problem of selection of scope is due partly to subject matter proliferation in social studies and also curriculum innovations. In the words of Preston (1985), "these innovations, influence not only method of study but seek to shape the social studies scope and sequence..." (p. $34)$.

The broad scope of the subject matter and the amount of material that could be included in social studies is a serious concern for social studies education. All agree that selection of what to study is a major issue in planning social studies instruction due to its "competing vision and contradictions" (Evans, 2004). Although social studies appears not to have an apparent core content, the challenge for social studies curriculum developers is to design an instructional programme that emphasizes depth of important ideas within appropriate breath of topic coverage. Thus, the selection of content must shape the needs of the learner and the nature of society as they complement each other. A well rounded social studies scope must therefore provide for the development of competencies and disposition which will enable the learner to be creativity, productive and innovative that serves to quality of life.

Social Studies has a limitless nature as a result a variety of subject areas and strategies are employed in the explanation of issues and problems. Thus, in explaining the scope of Social Studies, it draws materials from the disciplines such as geography, history, sociology, psychology, economics and civic education. Essential element of the knowledge and principle from these disciplines are integrated into a subject that stands on its own. Quashigah, (2014) sees the scope of Social Studies as issues-centered approach, subject centered approach and Civic-centered approach. Issues-centered approaches propose that Social Studies is the examination of specific issues. Social as well as personal problems and controversies are the primary content of the curriculum. Some 
would advocate the study of only perennial issues while others emphasize current or personal issues, such as moral dilemmas and values clarification.

\section{Goals and Objective of Social Studies}

Most writers in an attempt to define what the term social studies is also try to explain its goals and objectives. The term goal which is being used interchangeably with the word purpose refer to the long term expectations of social studies as distinct from objectives which are more specific and with short term expectation. Like its scope, there has been contentious debates' regarding the goals of social studies. Ross and Marker (2005) remarked that, "the very lack of agreement regarding the purpose of the field, perhaps more than any other characteristics has become the hallmark of social studies" (p. 2). Social Studies educators have always pitched a big tent, with plenty of room for diverse perspectives, and the response to conflicts over goals has most often been to look for how we could all just get along" (p. 7). This view is given credence by Ravitch (2003) when she echoes that "over the time, the leader of the field social studies (italics added) have frequently wrestled with their goals and purposes. She continues "the social studies field has readily redefined its aims to meet what so ever the socio political demands of the age were" (p.1).

The comments seem to suggest to a great extent the kind of disagreement and factionalism among those who advocate the various "tradition" of social studies education. It is therefore no wonder that Whelan (2001) comments that "the disagreement has become as adversarial as to threaten the field with factionalism, thereby undermining the pluralism from social studies has frequently benefited" (p. 43). While it appears there is no agreement among social studies educators over what the goals of social studies are, it is generally agreed that the primary pedagogical goal of social studies is to support students as they come to understand their world and have urgency as citizens (Vinson \& Ross, 2001). The main goal of social studies therefore is to promote citizenship education. Several authors however, have questioned the status of citizenship education as the main purpose of social studies. They argue that the term citizenship has not being clearly defined as goal of social studies (Leming, Ellington and Porter-Magee, (2003); Longstreet and Shane, (1993). Clearly, the social studies 'contrarians' position point to mind that there is no "scientifically objective" answer to the question of the purpose of citizenship education because those purpose are not things that can be discovered (Ross \& Marker, 2005).

In reaction to the above reasoning by the social studies contrarians, Banks (1990) writes that citizenship education is the primary focus of social studies in the school curriculum which promotes desirable participatory citizenship. According to Banks, "while the other curriculum areas also help students to attain some skills needed to participate in a democratic society, the social studies is the only curriculum area which has the development of civic competencies and skills as its main goals" (p.3). Subscribing to this views Tamakloe (1991) says that the main goal of social studies is to help students to be able to make informed decisions for the purpose of resolving personal problems and influencing public policy. To him these are important for the realization of the aims of citizenship. Ross and Marker (2005), state that "the purpose of social studies is citizenship education aimed at providing students opportunities for a model of problem solving" (p. 140).

Homana, Barber and Torney-Purta (2006) define citizenship as the opportunity provided by school to engage in meaningful learning experience... and other teaching strategies to facilitate their development as socially and politically responsible individuals. This is supported by the National Council for the Social Studies, (NCSS, 2006) which has long being leading advocate in the area of social studies. According to the NCSS the primary goal of education is to prepare students to be effective citizens and that through the curriculum students should have the opportunity to apply their civic knowledge to solve problems in schools. Martorella (2001) sums it up by saying; the basic purpose of social studies curriculum across the grade is to develop reflective, competent and concerned citizens. Reflective individuals are critical thinkers who make decisions and solve problems. Competent citizens possess a repertoire of skills to aid them in decision making and problem solving. Concerned citizens investigate their social world, identify issues as significant, exercise their responsibilities as members of a social community. Social studies should be seen as the head, the hand and the heart. The head represents reflection; the hand denotes competent and the heart symbolizes concern.

From the forgoing, it means that the social studies teacher has the sole responsibility of training student not only to develop their knowledge and skills but also the affective aspect of the individual, these are reflections of good citizens which Martorella refers to as "effective citizen". Martorella argues that the general purpose of social studies should be citizenship education; the objective is to produce reflective, competent and concern citizens who are critical and have inquiry mind. By thinking reflectively, students are able to apply the best course of action among alternatives. Reflective thinking therefore disrupts prejudices and deliberates on issues that are "fair to everyone concerned "(parker,2003).since citizenship is the central purpose of social studies as well as the bed rock upon which schools functions teachers should provide reflective classrooms to help close the chapter on problematic areas of our society. This will require effective method of reflection that should be applied to the school curriculum and organization (Kumashiiro, 2004). 


\section{Objectives of Social Studies}

In order to achieve social studies goals, specific objectives need to be stated. Like its goals, different writers state specific objectives for the realization of the general aims. However, despite different words used, the general consensus is to achieve the goal of citizenship. Barth (1983) writes: "teachers should help students gain knowledge, process information, develop skills to examine values and, finally to apply knowledge through an active civic participation". he said; if students practice these four objectives then social studies is taught as citizenship education" (p.4). According to Barth the social studies builds around four capacities and this is given credence by Banks (1990); Parker and Jaromelik (1997); Martorella (2001) and NCSS (2006). The four capacities are; acquisition of knowledge, acquisition of skills, development of desirable attitude and values and civic participation. Each capacity uniquely leads to responsible citizenship as they mirror the essential ingredient that characterizes sound social studies education. If students are to be effective citizens then they must possess the knowledge, skill, and values which will prepare them to take appropriate civic action as individual or as members of groups devoted to civic improvement. Gaining knowledge is an integral part of citizenship skills which allows for reflective decision making. Taba (1962) Knowledge of any sort is an index of one's acquaintance with reality. As an individual increases his knowledge he also increases his understanding of the world around him. Often the maturity and intelligence of an individual is judged by the amount of knowledge he possess (p. 212)

One important thing about the JHS Social Studies is the concept of integration. The Social Studies curriculum is integrated in nature. GES (2007), Social Studies comprises history, geography, economics, government, civics, and sociology. It means social studies gains its identity from the subject mentioned. According to Bishop (1985) integration is a re-grouping of ideas and knowledge between subjects and disciplines so as to provide a new and 'intellectually reputable curriculum". Integration refers to the process by which the interdependent parts of a larger whole relate or are brought into harmonious relationship with each other (Oliver, 1965).

Integration takes two forms that is the vertical and horizontal dimensions, within and across subjects and disciplines. Vertical integration takes place within a single discipline in order that the various levels of content such as ideas, concepts, facts, and principles build upon each other from simple to complex and from the known to the unknown. The purpose of this is to deepen learners' knowledge and understanding of issues. Horizontal integration, on the other hand, takes place across subject areas at particular level. Aside form of integration, we have types of integration. These are multidisciplinary integration, interdisciplinary integration and transdisciplinary integration. Multidisciplinary integration describes the process where two or more subjects are brought into relationship with each other such that what is learned in one discipline serves to reinforce what is learned in other disciplines. Whereas in multidisciplinary integration the contributing subjects retain their identity and logical structure, with interdisciplinary integration, the component subjects or contributing discipline lose their identity and are integrated into new area of study. Those who champion the transdisciplinary design believe that the curriculum should be built upon broad learning experiences or critical social problems (Adentwi, 2000).

\section{The Nature of the Junior High School Syllabus}

In order to examine the transaction process of any programme it is expected or required of an evaluator to give a detailed description of the programme highlighting its major features (Cobbold, 1999). This will help find out whether the programme is being transacted well or not as laid down by GES. The social studies syllabus for the Junior High School which could be described as an instructional programme describes in detail the teacher's strategies, approaches and the assessment to be used. In this section principles for implementing the syllabus are reviewed. In writing the syllabus, the top-down approach was used with the intent of developmental progression from the Junior High School to the senior secondary. The syllabus in particular focuses on "citizenship education" and this is given prominence in the introduction section of the syllabus which states the rationale for teaching social studies as:

Social studies is "Citizenship Education". The subject tries to prepare the individual to fit into society by equipping him/her with the kinds of knowledge, skills, value and attitudes needed for effective living within the society and for making constructive changes in the way of life of society. This will propel the nation to higher heights (GES, 2001).

From the syllabus it appears the incorporation of knowledge, skills value and attitudes are essential to the development of a holistic understanding of social studies. Disciplinary knowledge, used by students to construct learning is drawn primarily from geography, history economic and civic education by integrating them to create the subject social studies. The implication is that the teacher should possess the skills to integrate knowledge effectively by adopting a holistic approach to the teaching of social studies and at the same time maintains a focus on the subject matter. This is what Lucan (1981) calls "integration while preserving discipline identification" (p.63). 


\section{Aims and Objectives of the Social Studies Syllabus}

For effective implementation of the syllabus, statement of objectives to direct the learner is described in detail. Such objectives specify what the learner should be able to do at the end of each lesson to achieve a change in behavior. It is against this background that Tyler (1949) explains that "since the real purpose is not to have the instructor perform certain activities but to bring about significant changes in the students patterns of behavior, it becomes important to recognize that any statement of objectives of the school should be a statement of changes to take place in students" (p.44). The preamble of the 2001 syllabus is made up of the general aims. It is purposely designed to determine how pupils should behave in order to attain good citizenship. Specifically, the general aims of the Junior High School syllabus are the reflections of Blooms (1956) taxonomy of education which stresses on the cognitive, affective, and psychomotor domains.

The Social studies syllabus (GES, 2001) indicates the following:

(i) Understand the interrelationship between the social and the physical environment and their impact on the development of Ghana.

(ii) Understand the dynamics of development in the world and their impact on development in Ghana.

(iii) Recognize the major challenges facing Ghana and be able to develop basic knowledge and skills for dealing with such challenges.

(iv) Appreciate the Various components of the Environment and how these could be maintained to ensure sustainable development.

In the affective category, pupil should:

(i) Acquire the habit of developing skills and attitudes needed for peaceful co-existence and respect for people of other nations.

(ii) Acquire attitude and skills to develop a sense of national consciousness and national identify

In the psychomotor domain pupils should broadly

(i) Acquire some basic skills necessary for the resolution of social and environmental problem (2001, p.ii)

Basically the conclusion drawn is that the syllabus seeks to equip pupils with the knowledge, skills as well s attitudes and values to make informed decisions so as to be able to communicate and work effectively as a team in a multi-cultural and a interdependent world. The two broad dimensions of the syllabus are the development of the learner and his role as a good citizen. The expectation implies a mastery of fundamental competencies, fostered by a knowledge and appreciation of a heritage. The implications of the forgoing purposes/objectives of teacher education are that a credible teacher education programme must see to requisite and appropriate to the teaching profession, in the trainee teacher.

\section{Method, Techniques and Strategy of Teaching Social Studies}

Method, Techniques and Strategies are terms for three different levels of planning that a teacher thinks about when preparing to deliver a lesson. The three words should not, therefore, be used interchangeably. Although related, nonetheless, they refer to different things in the course of instructional delivery. (Ayaaba \& Odumah, 2013). Ayaaba and Odumah (2013) show clear distinction between and among method, technique and strategy of teaching. Here are the distinctions:

\section{Method of teaching}

It is a general term that is often used to refer to everything that a teacher does in the classroom in the course of a lesson delivery. In other words, a teacher's method of teaching refers to his or her overall approach to a lesson. They further explain that method of teaching are of two approaches, namely; transmission and discovery. Transmission method is a teacher-centred approach whereas discovery or problem solving is student-centred approach. They concluded that since Social Studies is a problem solving subject, the problem solving method is more preferable for the teaching and learning of Social Studies.

\section{Characteristics of a good Teaching Method}

Methods determine the quality of results. If comprehensive objectives of teaching social studies are to be realized in learners, then the learner should be exposed to good teaching methods. Good teaching methods should contain these features:

1. It should encourage creative expression.

2. It should also encourage co-operative and group work.

3. Arouse learners' interests

4. It should shift emphasis from verbalism and memorization.

5. It should train the techniques of self-study. 


\section{Technique of Teaching}

A technique of teaching refers to any activity teachers ask their students to perform during a lesson delivery. Such activities include dramatization, discussion, role play, simulation and brainstorming. The African Social and Environmental Studies Programme (ASESP, 1990), lists as many as 150 techniques of teaching Social Studies. In short, techniques are activities performed to achieve a method. In other words, the techniques that teachers employ during lesson delivery depend on their method of teaching. If the method is problem solving, the techniques to achieve that method might call for student participation in projects, group work, role play or discussion, etc. On the other hand, if the method is transmission, then the technique might be lecturing, recitation or dictation.

\section{Strategies of Teaching}

Strategy of teaching is the order or sequence of the technique that a teacher selects to teach a particular lesson. Bath (1990: 370) explains strategies as a way of "sequencing or organizing a giving selection of techniques". For example, during one lesson a teacher strategy could be an introductory lecture, followed by group work and finally a whole class discussion. It is importance to know that different teachers teaching the same topic (e. $\mathrm{g}$ in different schools) could employ different strategies. Hence, Dynneson and Gross (1990) note that a teaching strategy is a delivery system intended to establish, clarify, and explain students' ability to understand and interact with the subject matter. This implies that the subject matter is not just "presented". Rather, it behooves the teacher to select strategies that provides for the active involvement of student in the learning process. Just as it is with the techniques, a teacher's method of teaching also determines the strategy to use. It should now be amply clear that a teacher's method, technique and strategy of teaching are not the same. Admittedly, they are intricately related but certainly, there are subtle differences between them. From the above, it can be concluded that Social Studies teachers have wide range of methodology to the teaching of the subject at the basic school level. The Social Studies syllabus also makes suggestions on specific techniques for specific topics.

\section{Strategies of Teaching}

Strategy of teaching is the order or sequence of the technique that a teacher selects to teach a particular lesson. Bath (1990: 370) explains strategies as a way of "sequencing or organizing a giving selection of techniques". For example, during one lesson a teacher strategy could be an introductory lecture, followed by group work and finally a whole class discussion. This technique, sequenced one after the other are collectively referred to as teacher's strategy of teaching. It is importance to know that different teachers teaching the same topic (e. $\mathrm{g}$ in different schools) could employ different strategies. Hence, Dynneson and Gross (1990) note that a teaching strategy is a delivery system intended to establish, clarify, and explain students' ability to understand and interact with the subject matter. This implies that the subject matter is not just "presented". Rather, it behooves the teacher to select strategies that provides for the active involvement of student in the learning process. Just as it is with the techniques, a teacher's method of teaching also determines the strategy to use. It should now be amply clear that a teacher's method, technique and strategy of teaching are not the same. Admittedly, they are intricately related but certainly, there are subtle differences between them.

From the above, it can be concluded that Social Studies teachers have wide range of methodology to the teaching of the subject at the basic school level. The Social Studies syllabus also makes suggestions on specific techniques for specific topics.

\section{Brainstorming Technique Brainstorming Technique}

Brainstorming is an informal consideration of ideas or problems where the chief purpose is to solicit the suggestions, feelings ideas or consensus of members of the class (Parker, 2001). Orlich, et al (2004) note that "Brainstorming, is a simple and effective skill-building technique to use when a high level of creativity is desired" (p.282). Savage and Armstrong (2000) similarly posit that brainstorming as a technique of teaching is designed to help students develop original solutions to problems. It can be inferred from all these views that brainstorming is a quick way of generating ideas from students for later connection and reflection. During a brainstorming session, students share al the ideas that come to mind regarding the issue under consideration. They are encouraged to develop as many responses as possible to a focus problem. The objective of brainstorming, according to Parker (2001) is to get as many ideas from students as possible, no matter how outlandish they may seem.

\section{The Main Conditions that attract the use of Brainstorming are:}

Brainstorm is used when there is a problem and urgent consensus is needed. Brainstorm is used where there is the need to stimulate creativity among learners. It helps the teacher to find out from learners how they can provide solutions to an existing problem. Their responses would be essential for teaching and learning. It is also used when we want information on the general feelings or attitudes of a group towards a problem and its solution. 
It helps teachers to evaluate the effective aspect of the learners on a given topic. Some learners may prefer to use religious beliefs, traditions or scientific means of solving a problem. The following are the steps to follow when using brainstorming technique in teaching;

The brainstorming technique is used very often in the teaching of social and environmental studies.

First of all, present a solvable problem with many solutions to the class. A good example of such problem is the topic "The causes of poverty in Ghana". After the problem has been presented to the students, they are then encouraged to call out answers as soon as they think of them. In reference to the topic mentioned, the expected responses are laziness, curse, lack of employable skills, illiteracy, etc. All answers or ideas that are called out are accepted at face value and written down, without initial editorial or commentary on them. After all contributions are exhausted, lead the whole class to examine each point and either accept or reject it depending on whether or not the point is useful and relevant. For example, some of the causes of poverty are laziness, lack of employable skills, illiteracy but a curse cannot be considered as a cause, and hence should be rejected. Brainstorming encourages students to recognize and accept other students' views which are better than their own. It also gives learners the opportunity to get to know multiple meanings of concepts. The technique when effectively used will help students learn from each other. However, it is time consuming as all ideas have to be accepted and received initially. Again, if the topic is not well focused, a brainstorming session may lead to the generation of several irrelevant ideas, (Osborn, 1981)

\section{Lecture Technique}

Lecturing is the oldest and the most traditional technique of teaching. In this technique of teaching, a group of learners are made to listen attentively while the teacher or lecturer alone spouts on and on. All the analysis, the opinions on the issues, and generalizations are done by the teacher and embodied in the lecturer's notes, which are read out to the students. The teacher's delivery is generally expected to be done without interruption. However, the teacher may pause occasionally to ask or invite questions from learners (Ayaaba \& Odumah, 2013). During the process of lesson delivery, the teacher is talking or demonstrating to the learners most of the time. Generally, the role of the students is comparatively less active and more passive during instruction (Tamakloe, Atta \& Amedahe, 2005). The lecture technique is very effective and suitable in institutions where the learnerteacher ratio is high. It helps the teacher or lecturer to cover a lot of topics in the syllabus. The frequent use of lecture technique provides learners with an insight into the art of writing essays.

In spite of the above reasons, lecture technique does not take into consideration individual differences, encourages rote learning because the learner is expected to commit into memory the content of the teacher's lecture and reproduce same during examinations or assignments. Students who are taught Social Studies by rote are like parrots that have been taught to recite without understanding (Seefeldt, 2001).

\section{Educational Games/Simulations}

The terms games and simulations are often used interchangeably. However, they have whatever different meanings. Games usually involve a situation in which individuals or groups compete with one another within set of rules where there is a means of determining winners and losers. In short, games and real events. In the view of Kellough, (2003), educational games can be powerful tools for teaching and learning, and can have one to several of the following purpose: It adds variety and change pace, assesses students learning, enhances students' self-esteem, offers a break from the usual rigors of learning and motivates students to learn. Again, it provides learning about real issues through simulation and role play, provides problem solving situation and experience, and provides skills development and motivation through computer usage. Also, it provides skills development in inductive reasoning, skills development in communication and debate, reinforces convergent thinking, renews and reinforces subject matter learning.

Finally, it encourages learning through peer interaction, stimulates critical thinking and teaches both content and process. Simulation on the other hand, is designed to place participants in situations that closely resemble those found in the real world. As pointed out by Savage and Armstrong (2000), "simulations simplify reality to highlight certain key ideas" (p.276). This view is collaborated by Orlich et al (2004), who contend that "simulation is a representation or recreation of real object, problem, event or situation". Sometimes, simulation activities incorporate elements reality as well as element of games such as winning and losing. When this occurs, such activities are referred to as simulation games. Simulation activities, Savage and Amstrong, (2000), typically moves through four stages, namely, overview, training, activity and debriefing.

\section{Dramatization/Role Playing Technique}

Aggarwal, (2001:115 describes dramatization as a "synthetic are involving the purposive co-ordination and control of the delicate organs of speech and muscles... with the view to free and intelligent expression and emotions and ideas". The technique of drama involves students in the dramatization or role-playing of some events or feeling. This technique encourages students to learn by expressing in their own words the drama of an 
event. Some authorities used these two words interchangeably, and of course of what happens in drama is roleplaying. The difference between dramatization and roleplaying is that while dramatization needs rehearsal, roleplaying is spontaneous or extemporaneous. Olich et al (2014) opine that "role-playing is a process oriented group technique in which students act out or simulate a real life situation" (p.285) Clark, (1973) similarly asserts roleplay is an attempt to make a situation clear or to solve a problem by unrehearsed dramatization. Role-play is therefore an on-the-spot "acting out" of a situation, problem or incident.

The teacher may also use a formal drama in the classroom these involves the use of formal written drama or play to emphasize certain historical events. The written play is acted by few selected students. Role-playing is one way for students to explore issues or events in a group. It provides a means for testing ideas and plans of action in a practice situation, Through role playing students can experience how it feels to do something addition to participation in decision. Role-play serves several purposes that are consistent with the objectives of Social Studies. In the view of Savage and Amstrong, (2000), the techniques helps student to do the following,

i. Develop their interpersonal relation skills

ii. Recognize perceptive of others

iii. Appreciate perceptive of others

iv. Recognize the impact of one person's decisions on others ${ }^{\wedge}$

v. Master academic content by replicating roles of people who participated in real events

\section{The role-play}

At this stage, the teacher assigns roles or calls for volunteers. Outlines roles to the players in a concise and clear manner gives students a short time to get their thoughts together prior to beginning. Instruct those not involved to be observers. The observers should be given clear instructions on what to look for and what to write down. Start the role-play and allows it to run until the point has been made.

\section{Comparison between Role-Play and Simulations}

1. In role-play, there is little or no time for preparation, practice and rehearsal whereas in simulation, there is enough time for preparation, practice and rehearsal.

2. Few learners are selected for role-play whereas simulation involves the whole class.

3. Few resource materials are required for a role-play whereas a lot of resource materials are needed for simulation.

4. In role-play, players act in turns whereas simulation, calls for players acting simultaneously.

5. Role-play techniques are less expensive unlike simulation which is expensive.

6. Learners are familiar with events before role-play whereas in simulation, learners are not familiar with events.

\section{Advantages of Role-Play and Simulation}

1. They make learners very practical and meaningful. Learners see themselves as part and parcel of the lesson; therefore, rote learning is minimized.

2. Learners' interests are grouped and sustained throughout the lesson. Since the technique are not teacher-centered, learners performing all activities in the class and as a result, their interest is boosted.

3. They can be used to establish the value system of an individual or a group. This can help learners appreciate both social and personal values which can influence choice of behaviour.

4. They can play learners develop affective skills such as participatory, co-operation and tolerance. These are the qualities that help learners to become useful members of the society.

5. The enthusiasm and motivation of learners ends up in high retention and application of facts, skills, knowledge and attitudes. Research has revealed that learners are able to retain about $80 \%$ of what is taught, using role-play or simulation.

\section{Disadvantages of Role-Play and Simulation}

1. It may be time-consuming. The preparations that go into it demands a lot of previous time. The techniques, especially simulation, call for large number of learners participating hence the lengthy period.

2. They cannot be effective when used by a lazy teacher. For effective use of the technique teacher must take the learners through rehearsals and also such methods are not often used.

3. Not all topics lend themselves easily to the use of role-play and simulation

4. When the language capacity of learners is limited, the se of role-play may be difficult.

\section{Demonstration Technique}

Fianu, (1999) describes demonstration as a process during which "the teacher shows his pupils how to do 
something or perform a skill on their own" (p.166). Alorwor and Sadat (2011) share this view and stress that demonstration consist of showing learners how a new skill should be performed. This showing is done by the teacher while the students observe. Demonstration technique is based on the assumption that by seeing exactly what takes place, the learner will learn more effectively. Most students like demonstration because the person doing the demonstration is actively engaged in the learning activity rather than merely verbalizing about it. Demonstration, like most techniques of teaching can be used at any level of education in teaching any subject and for a variety of purposes.

Kellough (2000), demonstration severs the following purposes is to; assist students to recognize a solution to a given problem, demonstrate a thinking skill, model skill used in conflict resolution, establish problem reorganization, give students an opportunity for vicarious, participation in active learning, illustrate a particular point of lesson content, introduce a lesson or unit of study in a way that grapes students attention, reduce potential safety, hazards (where the teacher demonstrate with materials that are too dangerous for students to handle), save time and resources (as purposed to the entire class during that which is being demonstrated).

\section{Debate Technique of Teaching}

The debate as a teaching technique is a type of formal discussion that can be used to teach a number of topics in social studies. It is described as a teaching learning technique in which students are engaged in a healthy intellectual learning competition. In the of Savage and Armstrong, (2000), usually three learners constitute the pro team and another three form the con team. One learner also is selected to play the role of a critic. Members of the pro team are expected to gather as much information as they can to support the controversial issue. Similarly, members of the con team are supposed to gather such information that can be used to counteract or attack the same controversial proposal. Members of either team play an active role in arguing their team's case. The critic is to learn as much as he or she can about the positions of both teams. The purpose is to enable him or her ask probing questions at the end of the debate that will highlight the weakness of both positions.

\section{Field Trips}

Field trip or work may be explained as the teaching and learning which takes place outside the classroom or laboratories, usually planned and organized to take place within the school, the environs of the school, the local community or outside the local community.

\section{Organization of Educational Trips or Field Trips}

Teachers can organize the pupils/students for field trips to places of economic, historical, geographical and political importance and interest. Field trips are often planned to places where the students will be able to see in practice or reality what they have studied in class. Concepts generalizations, which were difficult to formulate become clearer, once the students are working applications on the concepts. Three main stages are involved in organizing field trips to enable pupils/students to use community resources.

\section{(ii) The First Stage}

The first stage has to do with the preparation which involves administrative arrangements and preparation of the class.

\section{Administrative Arrangement}

The teacher has to discuss the intended field trip/educational trip with the head of the school for his/her approval. Discuss with the pupils/students to show interest in the trip.

Preliminary personal contact should be made with the authorities at the place(s) to be visited. This should be followed by a formal letter indicating the following: The purpose of the visit, so that the authorities can prepare adequately for the pupils/students, the day/date/duration and time of the visit so that the authorities can reschedule their activities to conveniently welcome or receive the pupils/students to enable the host(s) or authorities to decide on the language to use as well as the level of the language, the teaching and learning resources to expose the pupils to, the approach to be adopted in explaining issues to the pupils/students and whom to guide them to mention but a few, the size of the class to enable the authorities to decide on whether or not to group them.

Following a favourable response from the authorities at the place(s) the class intends to visit, official permission should be sought from the District/Municipal/Metropolitan to ensure that the teacher is not held responsible for any unfortunate incident, particularly an accident. Provision should be made for food for the pupils/students if the place(s) to be visited is or are far away from the school. If it is a day' journey and the school is a boarding institution, packed lunch could be provided. If the trip will take more than a day, arrangements for food should be made, preferably from a nearby boarding institution or catering establishment. Provision should be made to accommodate the pupils if the trip will take more than a day, preferably in a nearly 
boarding institution. Make sure that the class is accompanied by teachers preferably in the ratio of 20:1. A female teacher should accompany the group if the school is a coeducational institution.

\section{(b) Preparation of the Class:}

Introduce the topic in a lesson preceding the trip and arouse the pupils/students' interest in the idea of organizing an educational trip. Organize pupils to gather background information on the place(s) they are going to visit. Help pupils to plan their activities. This should include the questions they will ask and the information they should record. If possible design questionnaire for the pupils to complete during the trip. In addition, assist pupils/students to prepare interview and observation guides/schedules. Give pupils/students certain rules of conduct to abide by in the course of the trip. This will ensure that they do not misconduct themselves to tarnish the image of the school.

\section{(ii) The Second Stage}

This is concerned with the activities during the trip. At this stage the required information on the topic should be gathered. Instruments to be used to gather the information should include the questionnaire, interview and observation guides/schedules. Students should note the information elicited by using these instruments in their jotters.

\section{(iii) The Third Stage}

This stage has to do with follow-up activities, evaluation of the field trip and culminating activities.

Follow-Up Activities: After a successful field trip, pupils should write a report on what they saw that they enjoyed most, what proved most (and least) interesting and what they feel they have learned from it. Their individual contributions can be used as a form of assessment of what they have learned or if this is not possible the teacher could give the class some kind of test.

\section{There could be group reports on the trip:}

The reports should be discussed in class and the salient points written on the chalkboard for the pupils/students to note them If there is sufficiently large number of aspects in interest to report on, the class can embark on a small project, preparing an exhibition on the class bulletin boards, displaying pictures and writing on what they saw and experienced.

\section{Evaluation of the field trips}

For his/her own records and for future reference, the teacher should try to assess whether or not the field trip was successful and in what ways.

\section{Culminating activities:}

After a field trip, the teacher should write letters of gratitude to the various people who made the trip possible.

\section{Advantages of Field Trip/Educational Trip}

It provides a sound and concrete basis for conceptualization. Concepts and generalizations which were difficult to formulate become clearer once the pupils/students see working application of those concepts.

It provides first-hand learning experiences. A field trip is planned to places, where pupils will be able to see in practice or reality what they have studied in class.

It gives an opportunity for improving social relationships among pupils and between peoples and teacher. It enhances co-operative learning.

It makes learning more meaningful and lasting.

Students learn to work on their own as they are given parts to complete for the group as assignments. Students learn to become good leaders and followers in their respective groups.

Through the use of field trip, pupils learn the skills of locating and gathering information through interviews, questionnaires and opinion surveys and critical observation.

Field trip can help to develop the skills of writing, sketching and measuring among others to demonstrate their understanding, (Gabrielsen, 1965)

\section{Disadvantages of field trip/educational trip}

It can be time consuming in terms of planning and organization as well as in what is learned. It could therefore upset the school time table the class may be away for the whole day. It can therefore throw the programme of the school out of gear.

It can involve additional expenses in terms of transport and feeding arrangements if what is to be studied is far away. 
Travelling can increase the risk of accidents.

Many teachers lack the skills to organize field trips. When field trips are not properly organized, the desired objectives cannot be achieved. Te result would be wastage of time, energy and resources.

(2) How to organize pupils/students to involve themselves in the celebration of festivals

Community resources can be used outside the classroom (school) to promote teaching and learning by organizing pupils/students to involve themselves in the celebration of festivals. In this way, pupils/students get direct or first-hand information or experience about the festivals. Through interview and critical observation of the festival, pupils get knowledge about the history behind the festival, the preparation towards it, the actual activities carried out during the festival and the significance as well as problems associated with it. The pupils/students therefore acquire knowledge in the form of acts and useful ideas about the festivals.

\section{(3) Organization of Pupils/Students to Participate in Community Activities}

Furthermore pupils/students can be organized to provide community services, such as tree planting and clean-up exercises and undertake social needs survey through which they can learn more about their environment. Pupils/students involvement or participation in community development activities can help imbue in them patriotism and a sense of belonging.

\section{Discussion Technique}

A discussion has been described as: A thoughtful situation where learners are allowed to give their views about a topic or problem. (Aggarwal, 1982). A thoughtful consideration of the relationship involved in a topic or problem under study. It is concerned with the analysis, comparisons, evaluation and conclusions of these relationships. Clarke (1973) in guided or controlled discussion, the teacher present learners with information about topic either by reading, showing a film or series of pictures to them and encouraging them to express their views. In the unguided or uncontrolled discussion, the teacher only presents the topic or problem to learners to study. Learners then express their views or offer solutions.

In the class discussion, the teacher presents a topic or problem to the whole class as one group. Individual learners express their views on the topic. For the group discussion, teacher divided the class or learners into groups. Groups express their collective view on a topic or problem presented by the teacher. This is usually done through a plenary discussion.

Panel Discussion; Small group of three to six around a table in the presence of an audience and hold a conversation on a controversial issue. Each student is assigned to give about five minutes talk of the chosen topic. While the speaker is delivering the rest of the class listen attentively and jots down points. After delivering the floor is opened for members of the class. This is a win-win satiation and the moderator (teacher) summarizes the various viewpoints given at the end of the discussion.

Whole Class Discussion: A whole class discussion as it implies involves the entire class population. Each pupil in the class is automatically drawn in onto the discussion session. In whole group discussion, the teacher takes the initiative of planning, teaching and evaluating a lesson. The discussion is focus on a single topic, a problem or an issue. The teacher serves as a guide or facilitator by posing relevant questions which is usually known to the teacher only. The teacher communicates to all students in a class as a group at the same time. Students in the class are allowed to share their thoughts but not all may have the chance of contributing to the lesson.

Group Discussion: The class is divided into manageable groups of about 5-10. Each group is given a component of a main topic or problem. Members in each group express their views on a topic. Each group then chooses it own leader and secretary to guide its own deliberations. They group must be of mixed ability type. During the discussion session the teacher goes from one group to another to assess their progress. The teacher directs the discussion by ask8ing leading questions. He also makes sure that the students are not digressing from the main issue. After the discussion the secretaries of each group present the outcome of their discussion to the whole class.

Debate Discussion: This type of discussion involves a controversial issue or topic which is debated in the class by all members of the class who which to be part of the discussion. It is quite different from the actual debate technique of teaching, which calls for the use of rules and principles.

\section{How to Use Discussion Technique:}

The following are guidelines for developing effective discussion techniques. The teacher should: Clearly identify the purpose of the discussion. Teacher should explain clearly the essence of the topic to learners. What they hope to achieve at the end of the lesson.

Suggest and guide the development of a topic to be discussed. Provide additional information to ensure effective and quality discussion. Assist students in maximum participation in the discussion. Allow every learner to contribute to the discussion. Both introvert and extrovert should be involved. Accept students' contributions as worthwhile no matter how limited the value may be. Teacher should not down play the contribution of any learner. The rationale is that, learners may feel free to make impact to the lesson. Suggest appropriate time 
schedules, or how long the discussion will last. Teachers should go by the time frame for the discussion, if it is 30 minutes discussion it should be respected. Provide summary remarks or conclusions based on what learners have discussed by either the teacher or learners. Highlight the main points and offer useful suggestions to bring out the relevant points and discard the irrelevant.

Evaluate the discussion activity for what went well and what needs to be improved. Talk about how the class conducted itself and those who made meaningful contributions should be commended and encourage them to do more.

\section{Advantages of Discussion}

It develops critical thinking in learners. Students would use evidences available to them to make conclusion on issues or problems at hand. Discussion technique reduces the incidence of hearsay as a basis to pass judgment, instead deliberate on issues to ascertain the truth or otherwise.

It offers a high level of learner participation. Because the technique is discussion most or many learners would like to present their facts and figures on the topics under discussion. Everybody tells what he/she knows about the topic; therefore such method involves large number of learners in the class.

It makes learners more tolerant as they become aware of different views which they may have to accommodate. It is a platform to nurture democracy and tolerance among learners. They become patience for one to make his/her points before another person.

It develops communication skills. Learners learn how to articulate their views, when a topic or issue is to be discussed. Research has revealed that those who speak well I public developed that the classroom through the use of discussion technique by teachers. Learners, who remained silence during their education, find it difficult to speak in public.

Learners' prejudices and biases are frequently modified when they are subjected to the scrutiny of the class. It helps learners to relax their assumptions which are not scientific.

\section{Disadvantages of Discussion}

It tends to be time-consuming. The opportunity given to every learner to express his/her view may consume or involve a lot of time. This is so, because adequate time would be given to students to deliberate on issues after a point has been raised, and this would involve much time.

It can lead to a pool of ignorance if learners are not well-prepared. Learners tend to rely on their common sense in the discussion, Most of the time such opinions are usually not factual.

It may also lead to unhealthy arguments and irresponsible utterances. Some students may go the extra mile of making irresponsible pronouncement. In such situations, it becomes difficult for the teacher to control the class.

It may and can be dominated by a few learners. They would "hijack" the class with their numerous facts and figures on the topic. This implies that the sky and low achievers are not usually catered for in a whole class discussion.

\section{A Resource Person}

A resource person is someone other than the regular class teacher or subject teacher, who is knowledgeable or skilled in a particular area of study and invited to schools to assist, facilitate and promote learning. Usually, the resource person is acclaimed to have a richer experience or knowledge or skills in that area of study than even the regular class teacher or subject teacher. A resource person can be a lawyer, medical officer, chief, linguist, traditional priest and a law enforcement officer to mention but a few. A resource person may be located in the immediate community or the wider community. A resource person could be invited by the teacher or a school committee. For example, a lawyer may be invited to handle a topic like the "Intestate Succession Law, PNDC Law 111" and a chief to present a talk on the topic like "The importance of the chieftaincy institution in Ghana".

\section{The Conditions That Necessitate the Invitation of a Resource Person to Present a Talk in a School}

Some conditions or factors necessitate the invitation of a resource person to assist in the teaching and learning process. When the teacher wants someone who is more knowledgeable in a topic being treated or has the requisite skills at performing an activity or a task at home to share his/her experience with the class to promote learning. When the teacher wants to introduce variety in the teaching and learning situation, the resource person's talk provides a pleasant variation from normal classroom instruction. The monotony associated with the appearance of teacher always in the class is broken. This arouses and sustains interest of pupils/students in the lesson. When the most appropriate or suitable teaching and learning resources to promote effective teaching and learning of a topic are not available and accessible in the school, but can be provided by a resource person. For instance, a medical officer or a nurse or a resource person from Ghana Aids Commission will be in the position to use suitable pictures, photographs and other teaching and learning aids to present a talk on a topic like "causes 
and effects of HIV/AIDS". These resources may not be available in the school to be used to ensure effective teaching and learning of the topic.

When the teacher wants to establish cordial school-community relationship by involving a resource person to the school to share his/her experience with pupils and the teacher he/she may tend to develop interest in the school. Consequently, he/she may readily assist the school by way of provision of teaching and learning resources or say a resource room for the teaching and learning of environmental and social studies. The yawning gap between the school and the community can be bridged. When the teacher needs to supplement his/her knowledge in a particular topic with those of a professional or an expert ,to be able to discuss it more meaningfully with his/her pupils or students.

\section{How to make Effective use of a Resource Person}

For pupils/students and the teacher to derive the maximum benefit from a resource person, the following steps should be considered.

(1) Teacher initial or preliminary preparation before inviting the resource person:

Seek permission from the head of the school for the invitation of a resource person. Introduce the topic to the pupils/students and tell them that a resource person will be invited to present a talk on it. Make sure that the topic selected is suitable or relevant. The topic must necessitate the invitation of a resource person. Make sure that the person has the special knowledge or skill required to achieve the desired objectives.

(2)

\section{- Preparation of a Resource Person}

Write officially to invite the resource person or contact him/her personally on the invitation.

Inform the resource person about the topic, its scope and importance to the pupils/students learning and the school's programme. Informing the resource person about the topic, will enable him/her prepare adequately for the talk. Inform the resource person of the day, date, time and duration of the talk as well as the venue. The day and date will enable the resource person to reschedule his/her activities. The time will ensure punctuality on the part of the resource person. The duration will guide the resource person to make judicious and effective use of the time allotted for the talk. The resource person being aware of the venue will not get stranded on the compound and waste time in locating the class for which the talk is meant.

Furnish the resource person with information about the characteristics of the pupils/students viz their age, cognitive level, interest, aspirations and the size of the class. This information will enable the resource person to select the suitable teaching and learning material and appropriate method to use. It will also enable the resource person to decide on the quantity of teaching and learning materials to bring along with him or her and the language to use a well as its level. Provide the resource person with information on the relevant teaching and learning materials available in the school which he/she could use. This will relieve the resource person of bringing along with him or her teaching and learning materials that are available and accessible in the school. Also, this information will enable the resource person to prepare and assemble all the relevant teaching and learning material for the talk or performance.

Make provision for the travelling and transport expenses of the resources person, if he or she is staying far away from the school. You may also have to make provision for refreshment and honorarium for the resource person.

Make sure that the relevant teaching and learning materials that may be required by the resource persons are available and put at the right places.

Create conducive atmosphere at the classroom or the venue for the talk. This includes sitting arrangements, lighting system and ventilation.

(3) . Preparation of Pupils/Students

Discuss the background of the resource person with pupils/students and explain why he/she is suitable for the topic. This will make students have confidence in him or her. Provide pupils/students with background information about the topic. This will make issues clearer to them right from the beginning .Discuss with pupils/students relevant questions to ask and issues to raise for clarification during and after the talk or performance.

(4) In the course of the talk or performance

For pupils/students to derive the maximum benefit from the talk or performance by a resource person, they should be asked to: Pay rapt attention so that they will understand the issues that will be discussed. Ask relevant questions and make effort to provide required responses to questions posed by the resource person, Raise relevant issues for clarification by the resource person. Make effective use of teaching and learning materials when directed to do so. Jot down salient points in their jotters or note books for discussion and future reference. Refrain from distracting the attention of their mates or the resource person.

(5) After the performance or talk by a resource person

Express your appreciation to the resource person by giving him/her an honorarium to settle travelling and transport expense. Write a letter of gratitude to the resource person. Inspect the note books or jotters of 
pupils/students for the core points they noted down. Discuss and stress on the salient issues raised by the resource person.

\section{Advantages of Resource Person}

Resource persons share their experiences with pupils/students to enable them to meaningfully understand concepts, generalizations and skills on particular topics. The experiences share by resource persons with the class contribute to the enhancement of knowledge and skills of teachers, which they can use subsequently to promote pupils'/students' learning. Resource persons provide pleasant variations from the normal classroom instruction. Pupils/students hear from different persons and thereby breaking the monotony or boredom associated with always listening to one another. This stimulates and sustains pupils/students' interests and promotes retention. Resource persons develop interest in schools and readily assist in various ways, when requested to do so. In other words, invitation of resource persons to schools, contribute to the development of cordial community relationship. Teacher's workloads are reduced when resource persons are invited to assist in the teaching and learning process.

\section{Disadvantages of the use of Resource Persons}

There is the tendency that the resource person may digress or the presentation or performance may be so detailed hat he/she end up confusing the pupil s/students. The school incurs expenses on resource persons by giving them refreshment an honorarium and sometimes bearing their transport expenses.

\section{Questions and Answer Technique of Teaching}

Questioning is fundamental to learning. This is because all knowledge starts from a question ASSESP (1992). It is for this reason that some educators regard questioning as one of the first teaching skills of an effective teacher. Aggarwal (2001) is of the opinion that 'the art of questioning is the most potent weapon in the educational armoury of the teacher" (p.144).

Questioning is intimately associated with good teaching. Good classroom questions act as prompts that help student to develop meaning as they engage with content presented in Social Studies lessons. That is why some educators regard teachers as 'professional question askers' (Savage \& Armstrong, 2001). The kind of questions the teacher asks in the class will reveal to the pupil the kind of thinking which is expected of them different types of questioning stimulate different type of thinking. It is therefore important for the teacher to be conscious of the type of question he/she asks. Therefore, Social Studies teachers who are not well-vested in questioning may ask questions that are irrelevant to the course of social studies education.

Asking good questions in class is not an easy task.

Teachers who lack good questioning skills are not able to psyche their students for learning and this may result in poor lesson delivery. The debate as a teaching technique is a type of formal discussion that can be used to teach a number of topics in social studies. It is described as a teaching learning technique in which students are engaged in a healthy intellectual learning competition. Savage and Armstrong (2000), usually three learners constitute the pro team and another three form the con team. One learner also is selected to play the role of a critic. Members of the pro team are expected to gather as much information as they can to support the controversial issue. Similarly, members of the con team are supposed to gather such information that can be used to counteract or attack the same controversial proposal. Members of either team play an active role in arguing their team's case. The critic is to learn as much as he or she can about the positions of both teams. The purpose is to enable him or her ask probing questions at the end of the debate that will highlight the weakness of both positions.

\section{Field trips}

Field trip or work may be explained as the teaching and learning which takes place outside the classroom or laboratories, usually planned and organized to take place within the school, the environs of the school, the local community or outside the local community.

\section{Organization of Educational trips or field trips}

Teachers can organize the pupils/students for field trips to places of economic, historical, geographical and political importance and interest. Field trips are often planned to places where the students will be able to see in practice or reality what they have studied in class. Concepts generalizations, which were difficult to formulate become clearer, once the students are working applications on the concepts. Three main stages are involved in organizing field trips to enable pupils/students to use community resources.

(ii) The First Stage

The first stage has to do with the preparation which involves administrative arrangements and preparation of the class. 


\section{Administrative Arrangement}

(i) .The teacher has to discuss the intended field rip/educational trip with the head of the school for his/her approval.

(ii) .Discuss with the pupils/students to show interest in the trip.

(iii) .Preliminary personal contact should be made with the authorities at the place(s) to be visited. This should be followed by a formal letter indicating the following:

-the purpose of the visit so that the authorities can prepare adequately for the pupils/students.

- the day/date/duration and time of the visit so that the authorities can reschedule their activities to conveniently welcome or receive the pupils/students to enable the host(s) or authorities to decide on the language to use as well as the level of the language, the teaching and learning resources to expose the pupils to, the approach to be adopted in explaining issues to the pupils/students and whom to guide them to mention but a few, -the size of the class to enable the authorities to decide on whether or not to group them. - Following a favourable response from the authorities at the place(s) the class intends to visit, official permission should be sought from the District/Municipal/Metropolitan to ensure that the teacher is not held responsible for any unfortunate incident, particularly an accident.

- $\quad$ Provision should be made for food for the pupils/students if the place(s) to be visited is or are far away from the school. If it is a day' journey and the school is a boarding institution, packed lunch could be provided. If the trip will take more than a day, arrangements for food should be made, preferably from a nearby boarding institution or catering establishment.

- $\quad$ Provision should be made to accommodate the pupils if the trip will take more than a day, preferably in a nearly boarding institution.

- Make sure that the class is accompanied by teachers preferably in the ratio of 20:1. A female teacher should accompany the group if the school is a coeducational institution.

(b) Preparation of the Class:

Introduce the topic in a lesson preceding the trip and arouse the pupils/students' interest in the idea of organizing an educational trip. Organize pupils to gather background information on the place(s) they are going to visit. Help pupils to plan their activities. This should include the questions they will ask and the information they should record. If possible design questionnaire for the pupils to complete during the trip. In addition, assist pupils/students to prepare interview and observation guides/schedules. Give pupils/students certain rules of conduct to abide by in the course of the trip. This will ensure that they do not misconduct themselves to tarnish the image of the school.

\section{(ii) The Second Stage}

This is concerned with the activities during the trip. At this stage the required information on the topic should be gathered. Instruments to be used to gather the information should include the questionnaire, interview and observation guides/schedules. Students should note the information elicited by using these instruments in their jotters.

\section{(iii) The Third Stage}

This stage has to do with follow-up activities, evaluation of the field trip and culminating activities.

Follow-Up Activities: After a successful field trip, pupils should write a report on what they saw that they enjoyed most, what proved most (and least) interesting and what they feel they have learned from it. Their individual contributions can be used as a form of assessment of what they have learned or if this is not possible the teacher could give the class some kind of test.

\section{There could be group reports on the trip:}

The reports should be discussed in class and the salient points written on the chalkboard for the pupils/students to note them If there is sufficiently large number of aspects in interest to report on, the class can embark on a small project, preparing an exhibition on the class bulletin boards, displaying pictures and writing on what they saw and experienced.

\section{Evaluation of the field trips}

For his/her own records and for future reference, the teacher should try to assess whether or not the field trip was successful and in what ways.

Culminating activities:

After a field trip, the teacher should write letters of gratitude to the various people who made the trip possible.

\section{Advantages of Field Trip/Educational Trip}

(i) . It provides a sound and concrete basis for conceptualization. Concepts and generalizations which were 
difficult to formulate become clearer once the pupils/students see working application of those concepts.

(ii) . It provides first-hand learning experiences. A field trip is planned to places, where pupils will be able to see in practice or reality what they have studied in class.

(iii) . It gives an opportunity for improving social relationships among pupils and between peoples and teacher. It enhances co-operative learning.

(iv) . It makes learning more meaningful and lasting.

(v) .Students learn to work on their own as they are given parts to complete for the group as assignments. Students learn to become good leaders and followers in their respective groups.

(vi) . Through the use of field trip, pupils learn the skills of locating and gathering information through interviews, questionnaires and opinion surveys and critical observation.

(vii) . Field trip can help to develop the skills of writing, sketching and measuring among others to demonstrate their understanding.

\section{Disadvantages of field trip/educational trip}

(i).It can be time consuming in terms of planning and organization as well as in what is learned. It could therefore upset the school time table the class may be away for the whole day. It can therefore throw the programme of the school out of gear.

(ii) . It can involve additional expenses in terms of transport and feeding arrangements if what is to be studied is far away.

(iii) . Travelling can increase the risk of accidents.

(iv) . Many teachers lack the skills to organize field trips. When field trips are not properly organized, the desired objectives cannot be achieved. The result would be wastage of time, energy and resources.

(2) . Organization of pupils/students to involve themselves in the celebration of festivals

Community resources can be used outside the classroom (school) to promote teaching and learning by organizing pupils/students to involve themselves in the celebration of festivals. In this way, pupils/students get direct or first-hand information or experience about the festivals. Through interview and critical observation of the festival, pupils get knowledge about the history behind the festival, the preparation towards it, the actual activities carried out during the festival and the significance as well as problems associated with it. The pupils/students therefore acquire knowledge in the form of acts and useful ideas about the festivals.

(3) . Organization of Pupils/Students to Participate in Community Activities

Furthermore pupils/students can be organized to provide community services, such as tree planting and clean-up exercises and undertake social needs survey through which they can learn more about their environment. Pupils/students involvement or participation in community development activities can help imbue in them patriotism and a sense of belonging.

\section{Discussion Technique}

A discussion has been described as: A thoughtful situation where learners are allowed to give their views about a topic or problem. (Aggarwal, 1982). A thoughtful consideration of the relationship involved in a topic or problem under study. It is concerned with the analysis, comparisons, evaluation and conclusions of these relationships.

\section{Types of Discussion Techniques}

There are four types of discussions technique of teaching. They are:

(i) Whole Class Discussion

(ii) Group discussion

(iii) Panel discussion

(iv) Debate discussion (Nacino-Brown et al,1992)

All of these types could be guided or controlled, or unguided or uncontrolled discussion. According to Clarke (1973) in guided or controlled discussion, the teacher present learners with information about topic either by reading, showing a film or series of pictures to them and encouraging them to express their views. In the unguided or uncontrolled discussion, the teacher only presents the topic or problem to learners to study. Learners then express their views or offer solutions. In the class discussion, the teacher presents a topic or problem to the whole class as one group. Individual learners express their views on the topic.

For the group discussion, teacher divided the class or learners into groups. Groups express their collective view on a topic or problem presented by the teacher. This is usually done through a plenary discussion.

\section{Panel Discussion}

Small group of three to six around a table in the presence of an audience and hold a conversation on a controversial issue, each student is assigned to give about five minutes talk of the chosen topic. While the 
speaker is delivering the rest of the class listen attentively and jots down points. After delivering the floor is opened for members of the class. This is a win-win satiation and the moderator (teacher) summarizes the various viewpoints given at the end of the discussion.

\section{Whole Class Discussion}

A whole class discussion as it implies involves the entire class population. Each pupil in the class is automatically drawn in onto the discussion session. In whole group discussion, the teacher takes the initiative of planning, teaching and evaluating a lesson. The discussion is focus on a single topic, a problem or an issue. The teacher serves as a guide or facilitator by posing relevant questions which is usually known to the teacher only. The teacher communicates to all students in a class as a group at the same time. Students in the class are allowed to share their thoughts but not all may have the chance of contributing to the lesson.

\section{Group Discussion}

The class is divided into manageable groups of about 5-10. Each group is given a component of a main topic or problem. Members in each group express their views on a topic. Each group then chooses its own leader and secretary to guide its own deliberations. They group must be of mixed ability type. During the discussion session the teacher goes from one group to another to assess their progress. The teacher directs the discussion by asking leading questions. He also makes sure that the students are not digressing from the main issue. After the discussion the secretaries of each group present the outcome of their discussion to the whole class.

\section{Debate Discussion}

This type of discussion involves a controversial issue or topic which is debated in the class by all members of the class who which to be part of the discussion. It is quite different from the actual debate technique of teaching, which calls for the use of rules and principles.

\section{How to Use Discussion Technique:}

The following are guidelines for developing effective discussion techniques. The teacher should:

- Clearly identified the purpose of the discussion. Teacher should explain clearly the essence of the topic to learners. What they hope to achieve at the end of the lesson.

- Suggest and guide the development of a topic to be discussed. Provide additional information to ensure effective and quality discussion.

- Assist students in maximum participation in the discussion. Allow every learner to contribute to the discussion. Both introvert and extrovert should be involved.

- Accept students' contributions as worthwhile no matter how limited the value may be. Teacher should not down play the contribution of any learner. The rationale is that, learners may feel free to make impact to the lesson.

- Suggest appropriate time schedules, or how long the discussion will last. Teachers should go by the time frame for the discussion, if it is 30 minutes discussion it should be respected.

- Provide summary remarks or conclusions based on what learners have discussed by either the teacher or learners. Highlight the main points and offer useful suggestions to bring out the relevant points and discard the irrelevant.

- Evaluate the discussion activity for what went well and what needs to be improved. Talk about how the class conducted itself and those who made meaningful contributions should be commended and encourage them to do more.

\section{Advantages of Discussion}

- It develops critical thinking in learners. Students would use evidences available to them to make conclusion on issues or problems at hand. Discussion technique reduces the incidence of hearsay as a basis to pass judgment, instead deliberate on issues to ascertain the truth or otherwise.

- It offers a high level of learner participation. Because the technique is discussion most or many learners would like to present their facts and figures on the topics under discussion. Everybody tells what he/she knows about the topic; therefore such method involves large number of learners in the class.

- It makes learners more tolerant as they become aware of different views which they may have to accommodate. It is a platform to nurture democracy and tolerance among learners. They become patience for one to make his/her points before another person.

- It develops communication skills. Learners learn how to articulate their views, when a topic or issue is to be discussed. Research has revealed that those who speak well I public developed that the classroom through the use of discussion technique by teachers. Learners, who remained silence during their 
education, find it difficult to speak in public.

- Learners' prejudices and biases are frequently modified when they are subjected to the scrutiny of the class. It helps learners to relax their assumptions which are not scientific.

\section{Disadvantages of Discussion}

- It tends to be time-consuming. The opportunity given to every learner to express his/her view may consume or involve a lot of time. This is so, because adequate time would be given to students to deliberate on issues after a point has been raised, and this would involve much time.

- It can lead to a pool of ignorance if learners are not well-prepared. Learners tend to rely on their common sense in the discussion, Most of the time such opinions are usually not factual.

- It may also lead to unhealthy arguments and irresponsible utterances. Some students may go the extra mile of making irresponsible pronouncement. In such situations, it becomes difficult for the teacher to control the class.

- It may and can be dominated by a few learners. They would "hijack" the class with their numerous facts and figures on the topic. This implies that the sky and low achievers are not usually catered for in a whole class discussion.

\section{A Resource Person}

A resource person is someone other than the regular class teacher or subject teacher, who is knowledgeable or skilled in a particular area of study and invited to schools to assist, facilitate and promote learning. Usually, the resource person is acclaimed to have a richer experience or knowledge or skills in that area of study than even the regular class teacher or subject teacher. A resource person can be a lawyer, medical officer, chief, linguist, traditional priest and a law enforcement officer to mention but a few. A resource person may be located in the immediate community or the wider community. A resource person could be invited by the teacher or a school committee. For example, a lawyer may be invited to handle a topic like the "Intestate Succession Law, PNDC Law 111" and a chief to present a talk on the topic like "The importance of the chieftaincy institution in Ghana".

The Conditions That Necessitate the Invitation of a Resource Person to Present a Talk in a School

Some conditions or factors necessitate the invitation of a resource person to assist in the teaching and learning process.

(i) .When the teacher wants someone who is more knowledgeable in a topic being treated or has the requisite skills at performing an activity or a task at home to share his/her experience with the class to promote learning.

(ii) .When the teacher wants to introducer variety in the teaching and learning situation. The resource person's talk provides a pleasant variation from normal classroom instruction. The monotony associated with the appearance of teacher always in the class is broken. This arouses and sustains interest of pupils/students in the lesson.

(iii) When the most appropriate or suitable teaching and learning resources to promote effective teaching and learning of a topic are not available and accessible in the school, but can be provided by a resource person. For instance, a medical officer or a nurse or a resource person from Ghana Aids Commission will be in the position to use suitable pictures, photographs and other teaching and learning aids to present a talk on a topic like "causes and effects of HIV/AIDS". These resources may not be available in the school to be used to ensure effective teaching and learning of the topic.

(iv). When the teacher wants to establish cordial school-community relationship. By involving a resource person to the school to share his/her experience with pupils and the teacher he/she may tend to develop interest in the school. Consequently, he/she may readily assist the school by way of provision of teaching and learning resources or say a resource room for the teaching and learning of environmental and social studies. The yawning gap between the school and the community can be bridged.

(v) .When the teacher needs to supplement his/her knowledge in a particular topic with those of a professional or an expert to be able to discuss it more meaningfully with his/her pupils or students.

\section{How to make Effective use of a Resource Person}

For pupils/students and the teacher to derive the maximum benefit from a resource person, the following steps should be considered.

\section{(1).Teacher initial or preliminary preparation before inviting the resource person:}

- Seek permission from the head of the school for the invitation of a resource person.

- Introduce the topic to the pupils/students and tell them that a resource person will be invited to present a talk on it.

- Make sure that the topic selected is suitable or relevant. The topic must necessitate the invitation of a resource person. 
- Make sure that the person has the special knowledge or skill required to achieve the desired objectives.

\section{. Preparation of a Resource Person}

- Write officially to invite the resource person or contact him/her personally on the invitation.

- Inform the resource person about the topic, its scope and importance to the pupils/students learning and the school's programme. Informing the resource person about the topic, will enable him/her prepare adequately for the talk.

- Inform the resource person of the day, date, time and duration of the talk as well as the venue. The day and date will enable the resource person to reschedule his/her activities. The time will ensure punctuality on the part of the resource person. The duration will guide the resource person to make judicious and effective use of the time allotted for the talk. The resource person being aware of the venue will not get stranded on the compound and waste time in locating the class for which the talk is meant.

- Furnish the resource person with information about the characteristics of the pupils/students viz their age, cognitive level, interest, aspirations and the size of the class. This information will enable the resource person to select the suitable teaching and learning material and appropriate method to use. It will also enable the resource person to decide on the quantity of teaching and learning materials to bring along with him or her and the language to use a well as its level.

- Provide the resource person with information on the relevant teaching and learning materials available in the school which he/she could use. This will relieve the resource person of bringing along with him or her teaching and learning materials that are available and accessible in the school. Also, this information will enable the resource person to prepare and assemble all the relevant teaching and learning material for the talk or performance.

- Make provision for the travelling and transport expenses of the resources person, if he or she is staying far away from the school. You may also have to make provision for refreshment and honorarium for the resource person.

- Make sure that the relevant teaching and learning materials that may be required by the resource persons are available and put at the right places.

- Create a conducive atmosphere at the classroom or the venue for the talk. This includes sitting arrangements, lighting system and ventilation. .Preparation of Pupils/Students

- Discuss the background of the resource person with pupils/students and explain why he/she is suitable for the topic. This will make students have confidence in him or her.

- Provide pupils/students with background information about the topic. This will make issues clearer to them right from the beginning

- Discuss with pupils/students relevant questions to ask and issues to raise for clarification during and after the talk or performance.

(4) In the course of the talk or performance

- For pupils/students to derive the maximum benefit from the talk or performance by a resource person, they should be asked to:

- $\quad$ Pay rapt attention so that they will understand the issues that will be discussed.

- Ask relevant questions and make effort to provide required responses to questions posed by the resource person,

- Raise relevant issues for clarification by the resource person.,

- Make effective use of teaching and learning materials when directed to do so.

- Jot down salient points in their jotters or note books for discussion and future reference.

- Refrain from distracting the attention of their mates or the resource person.

(5) After the performance or talk by a resource person

- Express your appreciation to the resource person by giving him/her an honorarium to settle travelling and transport expenses

- Write a letter of gratitude to the resource person.

- Inspect the note books or jotters of pupils/students for the core points they noted down.

- Discuss and stress on the salient issues raised by the resource person.

\section{Advantages of Resource Person}

(i) Resource persons share their experiences with pupils/students to enable them to meaningfully understand concepts, generalizations and skills on particular topics.

(ii) . The experiences share by resource persons with the class contribute to the enhancement of knowledge and 
skills of teachers, which they can use subsequently to promote pupils'/students' learning.

(iii) . Resource persons provide pleasant variations from the normal classroom instruction. Pupils/students hear from different persons and thereby breaking the monotony or boredom associated with always listening to one another. This stimulates and sustains pupils/students' interests and promotes retention

(iv) . Resource persons develop interest in schools and readily assist in various ways, when requested to do so. In other words, invitation of resource persons to schools, contribute to the development of cordial community relationship.

(v) . Teacher's workloads are reduced when resource persons are invited to assist in the teaching and learning process.

\section{Disadvantages of the use of Resource Persons}

(i) .There is the tendency that the resource person may digress or the presentation or performance may be so detailed hat he/she end up confusing the pupils/students.

(ii) .The school incurs expenses on resource persons by giving them refreshment an honorarium and sometimes bearing their transport expenses.

\section{Questions and Answer Technique of Teaching}

Questioning is fundamental to learning. This is because all knowledge starts from a question ASSESP (1992). It is for this reason that some educators regard questioning as one of the first teaching skills of an effective teacher. Aggarwal (2001) is of the opinion that 'the art of questioning is the most potent weapon in the educational armoury of the teacher' (p.144).

Questioning is intimately associated with good teaching. Good classroom questions act as prompts that help student to develop meaning as they engage with content presented in Social Studies lessons. That is why some educators regard teachers as 'professional question askers' (Savage \& Armstrong, 2001). The kind of questions the teacher asks in the class will reveal to the pupil the kind of thinking which is expected of them different types of questioning stimulate different type of thinking. It is therefore important for the teacher to be conscious of the type of question he/she asks. Therefore, Social Studies teachers who are not well-vested in questioning may ask questions that are irrelevant to the course of social studies education.

Asking good questions in class is not an easy task. Teachers who lack good questioning skills are not able to psyche their students for learning and this may result in poor lesson delivery.

\section{The Concept "Perception"}

Perception can be defined as our recognition and interpretation of sensory information. Perception also includes how we respond to the information. We can think of perception as a process where we take in sensory information from our environment and use that information in order to interact with our environment. Perception allows us to take the sensory information in and make it into something meaningful. For example, let's look at our perception of words. Each letter of the alphabet is in itself a singular letter. When we perceive words, we think of them as one singular unit that is made up of smaller parts called letters. It is through this organization of letters into words that we are able to make something meaningful. That is, we perceive an entire word, and this word has a specific meaning that can be found in the dictionary. Perception is also necessary for us to survive in our environment. For example, before parents feed their babies micro waved food, they taste it in order to make sure that the temperature isn't too hot. This involves using sensory information (touch and taste) to make sure that the food is not dangerous for the infant. Before we cross a busy street, we rely on our hearing and sight to make sure a car is not coming. Without the sensory information, we would not be able to judge which food was too hot or when an appropriate time to cross the street would be, which could put us and our children in danger.

It is therefore important to examine social studies teachers' perception of the subject they teach. The Social studies syllabus provides opportunities for learners to interact with an integrated body of knowledge, skills, values, and attitudes, as well as modes of enquiry which will help learners to develop holistically. (Social Studies Syllabus, 2007). By this, they are exposed to broader perspective of their social and physical environment. Teachers' understanding of a subject to a very large extent, influence their method of teaching. The chart below shows how philosophers differ in knowledge. 
Philosophy and Education Continuum Chart

\begin{tabular}{|c|c|c|c|c|}
\hline \multicolumn{5}{|c|}{ 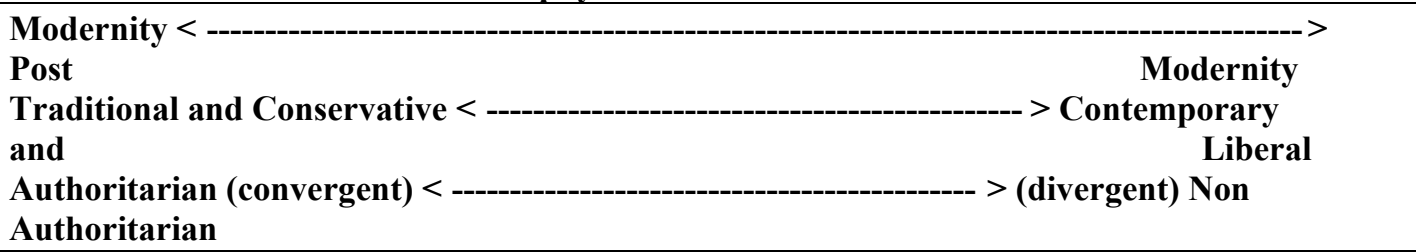 } \\
\hline $\begin{array}{l}\text { General or } \\
\text { World } \\
\text { Philosophi } \\
\text { es }\end{array}$ & $\begin{array}{l}\text { Idealism: } \\
\text { Ideas are the } \\
\text { only true } \\
\text { reality, the } \\
\text { only thing } \\
\text { worth } \\
\text { knowing. } \\
\text { Focus: Mind }\end{array}$ & $\begin{array}{l}\text { Realism: } \\
\text { Reality exists } \\
\text { independent } \\
\text { of human } \\
\text { mind. World } \\
\text { of physical } \\
\text { objects } \\
\text { ultimate } \\
\text { reality. } \\
\text { Focus: Body }\end{array}$ & $\begin{array}{l}\text { Pragmatism: } \\
\text { Universe is } \\
\text { dynamic, } \\
\text { evolving. } \\
\text { Purpose of } \\
\text { thought is } \\
\text { action. Truth is } \\
\text { relative. } \\
\text { Focus: } \\
\text { Experience }\end{array}$ & $\begin{array}{l}\text { Existentialism: } \\
\text { Reality is } \\
\text { subjective, within } \\
\text { the individual. } \\
\text { Individual rather } \\
\text { than external } \\
\text { standards. } \\
\text { Focus: Freedom }\end{array}$ \\
\hline $\begin{array}{l}\text { Originator( } \\
\text { s) }\end{array}$ & $\begin{array}{l}\text { Plato, } \\
\text { Socrates }\end{array}$ & Aristotle & Pierce, Dewey & $\begin{array}{l}\text { Sartre, } \\
\text { Kierkegaard }\end{array}$ \\
\hline $\begin{array}{l}\text { Curricular } \\
\text { Emphasis }\end{array}$ & $\begin{array}{l}\text { Subject } \\
\text { matter of } \\
\text { mind: } \\
\text { literature, } \\
\text { history, } \\
\text { philosophy, } \\
\text { religion }\end{array}$ & $\begin{array}{l}\text { Subject } \\
\text { matter of } \\
\text { physical } \\
\text { world: } \\
\text { science, math }\end{array}$ & $\begin{array}{l}\text { Subject matter } \\
\text { of social } \\
\text { experience. } \\
\text { Creation of new } \\
\text { social order }\end{array}$ & $\begin{array}{l}\text { Subject matter of } \\
\text { personal choice }\end{array}$ \\
\hline $\begin{array}{l}\text { Teaching } \\
\text { Method }\end{array}$ & $\begin{array}{l}\text { Teach for } \\
\text { handling } \\
\text { ideas: }\end{array}$ & $\begin{array}{l}\text { Teach for } \\
\text { mastery of } \\
\text { facts and }\end{array}$ & $\begin{array}{l}\text { Problem } \\
\text { solving: Project } \\
\text { Method }\end{array}$ & $\begin{array}{l}\text { Individual as entity } \\
\text { within social } \\
\text { context }\end{array}$ \\
\hline
\end{tabular}

\begin{tabular}{|c|c|c|c|c|}
\hline & $\begin{array}{l}\text { lecture, } \\
\text { discussion }\end{array}$ & $\begin{array}{l}\text { basic skills: } \\
\text { demonstratio } \\
\text { n, recitation }\end{array}$ & & \\
\hline $\begin{array}{l}\text { Character } \\
\text { Developme } \\
\text { nt }\end{array}$ & $\begin{array}{l}\text { Imitating } \\
\text { examples, } \\
\text { heroes }\end{array}$ & $\begin{array}{l}\text { Training in } \\
\text { rules of } \\
\text { conduct }\end{array}$ & $\begin{array}{l}\text { Making group } \\
\text { decisions in } \\
\text { light of } \\
\text { consequences }\end{array}$ & $\begin{array}{l}\text { Individual } \\
\text { responsibility for } \\
\text { decisions and } \\
\text { preferences }\end{array}$ \\
\hline $\begin{array}{l}\text { Related } \\
\text { Education } \\
\text { al } \\
\text { Philosophi } \\
\text { es }\end{array}$ & $\begin{array}{l}\text { Perennialis } \\
\text { M } \\
\text { Focus: } \\
\text { Teach ideas } \\
\text { that are } \\
\text { everlasting. } \\
\text { Seek } \\
\text { enduring } \\
\text { truths which } \\
\text { are constant, } \\
\text { Not } \\
\text { changing, } \\
\text { through } \\
\text { great } \\
\text { literature, } \\
\text { art, }\end{array}$ & $\begin{array}{l}\text { Essentialism } \\
\text { : } \\
\text { Focus: Teach } \\
\text { the common } \\
\text { core, "the } \\
\text { basics" of } \\
\text { information } \\
\text { and skills } \\
\text { (cultural } \\
\text { heritage) } \\
\text { needed for } \\
\text { citizenship. } \\
\text { (Curriculum } \\
\text { can change } \\
\text { slowly) }\end{array}$ & $\begin{array}{l}\text { Progressivism: } \\
\text { Focus: Ideas } \\
\text { should be tested } \\
\text { by active } \\
\text { experimentation } \\
\text {. Learning } \\
\text { rooted in } \\
\text { questions of } \\
\text { learners in } \\
\text { interaction with } \\
\text { others. } \\
\text { Experience and } \\
\text { Student } \\
\text { centered. }\end{array}$ & $\begin{array}{l}\text { Reconstructionis } \\
\text { m/ } \\
\text { Critical Theory } \\
\text { Focus: Critical } \\
\text { pedagogy: } \\
\text { Analysis of world } \\
\text { events, } \\
\text { controversial } \\
\text { issues and } \\
\text { diversity to } \\
\text { provide vision for } \\
\text { better world and } \\
\text { social change. }\end{array}$ \\
\hline
\end{tabular}




\begin{tabular}{|c|c|c|c|c|}
\hline & $\begin{array}{l}\text { philosophy, } \\
\text { religion. }\end{array}$ & & & \\
\hline $\begin{array}{l}\text { Key } \\
\text { Proponent } \\
\text { s }\end{array}$ & $\begin{array}{l}\text { Robert } \\
\text { Hutchins, } \\
\text { Jacque } \\
\text { Maritain, } \\
\text { Mortimer } \\
\text { Adler, } \\
\text { Allan } \\
\text { Bloom }\end{array}$ & $\begin{array}{l}\text { William } \\
\text { Bagley; } \\
\text { Arthur } \\
\text { Bestor, } \\
\text { E. D. Hirsch, } \\
\text { Chester Finn, } \\
\text { Diane } \\
\text { Ravitch, } \\
\text { Theodore } \\
\text { Sizer }\end{array}$ & $\begin{array}{l}\text { John Dewey, } \\
\text { William } \\
\text { Kilpatrick }\end{array}$ & $\begin{array}{lr}\text { George } & \text { Counts, } \\
\text { J. } & \text { Habermas, } \\
\text { Ivan } & \text { Illich, } \\
\text { Henry } & \text { Giroux, } \\
\text { Paulo Freire } & \end{array}$ \\
\hline $\begin{array}{l}\text { Related } \\
\text { Theories of } \\
\text { Learning } \\
\text { (Psycholog } \\
\text { ical } \\
\text { Orientatio } \\
\text { ns) }\end{array}$ & $\begin{array}{l}\text { Informatio } \\
\mathbf{N} \\
\text { Processing } \\
\text { The mind } \\
\text { makes } \\
\text { meaning } \\
\text { through } \\
\text { symbol- } \\
\text { processing } \\
\text { structures of } \\
\text { a fixed body }\end{array}$ & $\begin{array}{ll}\text { Behaviorism } \\
\text { Behavior } \\
\text { shaped } \\
\text { design and } & \\
\text { determined } & \\
\text { by forces in } & \\
\text { environment. } & \\
\text { Learning } \\
\text { occurs } \\
\text { result as } \\
\text { reinforcing }\end{array}$ & $\begin{array}{l}\text { Cognitivism/ } \\
\text { Constructivis } \\
\text { M } \\
\text { Learner actively } \\
\text { constructs own } \\
\text { understandings } \\
\text { of reality } \\
\text { Through } \\
\text { interaction with } \\
\text { environment } \\
\text { and reflection }\end{array}$ & $\begin{array}{l}\text { Humanism } \\
\text { Personal freedom, } \\
\text { choice, } \\
\text { responsibility. } \\
\text { Achievement } \\
\text { motivation towards } \\
\text { highest levels. } \\
\text { Control of own } \\
\text { destiny. Child } \\
\text { centered. }\end{array}$ \\
\hline
\end{tabular}

\begin{tabular}{|c|c|c|c|c|}
\hline & $\begin{array}{l}\text { of } \\
\text { knowledge. } \\
\text { Describes } \\
\text { how } \\
\text { information } \\
\text { is received, } \\
\text { processed, } \\
\text { stored, and } \\
\text { retrieved } \\
\text { from } \\
\text { mind. }\end{array}$ & $\begin{array}{l}\text { responses to } \\
\text { stimuli. } \\
\text { Social } \\
\text { Learning } \\
\text { Learning by } \\
\text { observing and } \\
\text { imitating } \\
\text { others. }\end{array}$ & $\begin{array}{l}\text { on actions. } \\
\text { Student- } \\
\text { centered } \\
\text { learning around } \\
\text { conflicts to } \\
\text { present } \\
\text { knowing } \\
\text { structures. }\end{array}$ & $\begin{array}{l}\text { Interaction with } \\
\text { others. }\end{array}$ \\
\hline $\begin{array}{l}\text { Key } \\
\text { proponent } \\
\text { s }\end{array}$ & $\begin{array}{l}\text { R. M. } \\
\text { Gagne, } \\
\text { E. Gagne, } \\
\text { Robert } \\
\text { Sternberg, } \\
\text { J.R. } \\
\text { Anderson }\end{array}$ & $\begin{array}{l}\text { Ivan Pavlov, } \\
\text { John Watson, } \\
\text { B.F. Skinner, } \\
\text { E.L. } \\
\text { Thorndike, } \\
\text { Albert } \\
\text { Bandura }\end{array}$ & $\begin{array}{l}\text { Jean Piaget, } \\
\text { U. } \\
\text { Bronfenbrenner } \\
\text { Jerome Bruner, } \\
\text { Lev Vygotsky }\end{array}$ & $\begin{array}{r}\text { Rousseau } \\
\text { Maslow } \\
\text { Rogers } \\
\text { Combs }\end{array}$ \\
\hline
\end{tabular}

(C) 1999 LeoNora M. Cohen, OSU - School of Education

Relevance of the Philosophy and Education Continuum chart to the Study

This chart is significant to the study, because research question two talks about the techniques Social Studies employ in teaching the subject. The popular technique use by teachers may form the basis of their perception of the subject Social Studies. The chart is significant to the study because it brings forward different philosophies of education. This means that there is variation in understanding of what knowledge is about. Philosophers like Plato and Socrates, who thought that the focus of knowledge is in the mind, believe that the best to ensure that knowledge is focus in the mind is to employ teaching techniques like lecture and discussion. Learners' character development will be on imitating examples of heroes. In a sharp contrast, the proponents of Realism think the focus of knowledge is through the body. To them, subject matter of physical world, eg Science and Mathematics, can be taught through demonstration and recitation. Unlike the idealists, character development is training in rules of conduct. Social Studies teachers who think in line of the Essentialism may focus their teaching on providing basic information and needed for Citizenship Education, whereas the Progressivism inclined will focus their teaching on test by active experimentation. This is clear indication that what Social Studies teachers think 
about the subject will greatly determine how they teach.

\section{Academic Competency and Professional Background of Teachers}

Effective implementation of any programme depends to a large extent on teacher competency. The professional teacher is therefore expected to exhibit his or her skill and knowledge of the subject matter within a given period. Subject matter knowledge according to Shulman (1987) refers to the amount and organization of the knowledge per se in the mind of the teacher. Melton (1994) says competency is that which is adequate for the purpose, suitable, sufficient, qualified and capable. Stanley (1991) contends that the effectiveness of the teacher depends on his knowledge of the subject matter. To Stanley therefore knowledgeable teachers do not only know more about the relationship among the part of knowledge, but how disciplines are related to the other areas of knowledge and equally important, how best to represent this knowledge so that students would come to understand it. He concludes that: Effective teachers continually monitor their students' progress and give them enough homework. This is done gradually to ensure that the students learn rapidly. In effect, a teacher's subject matter competency depends to a large extent on how he is able to demonstrate his knowledge through good practices in the classroom. On their part, Jordan and Powell (1995) indicate that to be competent are both to have a set of skills to employ them using a flexible responsive set of higher order strategies that bring that desired outcomes.

MacNamara, (1991) writing on effective teaching suggested the following argument for teachers' subject matter knowledge.

1. If the aim of teaching is to enhance children understand the teachers' themselves must have a flexible and sophisticated understanding of subject matter knowledge in order to achieve this purpose in the classroom. At the heart of teaching is the notion of forms of representation and the significant degree of teaching entails knowing about and understanding ways of representing and formulating subject matter so that it can be understood by children. This in turn requires teachers to have a sophisticated understanding of a subject and its interaction with other subjects.

2. Teachers' subject matter knowledge influences the way in which they teach and teachers' who know about a subject will be more interesting and adventurous in the ways in which they teach and more effective. Teachers' with only a limited knowledge of the subject may avoid teaching difficult or complex aspects of it and teach in a didactic manner without pupils' participation and questioning and fails to draw upon children's experience. Knowledge of subject matter is necessary to evaluate textbook and other teaching aid medium of instructions (p.113).

Certainly, these three suggestions indicate that if the social programme is to be well transacted then teachers' subject matter knowledge is very important. It appears from this point that the teacher effectiveness indispensable factor if successful teaching and learning should go on in the schools. Based upon analysis of teachers' effectiveness in social studies Dynneson and Gross (1999) identified ten general principles found to be important in teaching any subject effectively.

These include;

1. clarity of presentation

2. variety in strategies and activities used

3. $\quad$ staying on task

4. engaging students activities in learning processes without disruptions

5. providing clear structure in teaching

6. engaging students in cognitive development

7. expanding upon the knowledge base students' have

8. student participation

9. Teacher enthusiasm of the subject matter being taught.

Using these principles "Dynesson and Gross proposed what they called "effective social studies teacher behaviour." From these principles it is evident that the classroom teacher is important in the implementation of any instructional programme. In effect competency refers to adequate knowledge preparation of teachers and how they affect students' behaviour. As Rice (2003) puts it, teacher content coursework in the subject area taught and pedagogy contribution to positive teacher effectiveness at all grade levels. Laczko-Kerr \& Berliner (2002) contend that as subject matter area becomes more complex; teachers need a much deeper knowledge of that subject matter area in order to be effective. This is critical as it is associated with students learning (Hill, Rowan and Ball, 2004; Goldhaber and Brewer, 2000).

\section{Professional Training and Experience of Social Studies Teachers}

In addition to teachers' academic knowledge, sound professional training and experience is believed to be a means of accumulation knowledge and skills for the improvement of their classroom practice. Leming (1990) 
asserts that the characteristics of social studies teachers such as professional values and experience are potentially valuable for understanding the art of teaching and influence of teachers. Desimone, Porter, Garet, Yoon and Birman, (2002) professional development is essential to improving teacher quality and that changes in teaching practice will occur if teachers have a consistent and high quality professional training. Research by Wenglinsky (2002) indicates that the link between teacher quality and students' performance supports the belief that teachers' input can influence student performance. He notes further that the greatest influence on students' achievements come from the classroom practice and the professional development that supports them. Wenglinsky' s research indicates that "regardless of the level of preparation students bring into classroom, decisions that teachers make about classroom practice can either greatly facilitate students learning or serve as an obstacle to it" (p. 7). Darling-Hammond (2000) asserts that assigning teachers to teach course that they are not trained to teach has a negative effect on students' achievement. Darling-Hammond,

Berry \& Thoreson (2001) add that teachers who are trained and teach in the area in which they are certified outperform teachers who have no certification. Goldhaber \& Brewer (2000) on their part note that, not all certified teachers' are assigned to teach in the areas for which they have been trained. In support of Goldhaber and Brewer, Ingersoll (2003) add that large numbers of teachers are assign duties for which their certification "irrelevant". One of the least recognize of this courses is the phenomenon known as "out of field teaching", that is, teachers assigned to teach subject for which they have little training or education. In a similar sentiment, Seamstrom, Gruber, Henke, McGrath and Cohen (2002) state that many teachers' lack adequate academic training, certificate or both.

In attempt $t$ identify the limitations on effective social studies instruction in the Kissi Districk of Kenya, Ossindi (1992) are concluded that untrained teachers and lack of in service training education were major limiting factors. Rossenfield, (2004) agrees by starting that social studies teachers receive fewer professional development opportunities that teachers in other disciplines. If social studies teaching were to be effective, inservice training is necessary as a key means through which teachers are provided with the necessary knowledge and skills to improve upon their performance in classroom. Research work by Darling-Hammond (2000) on teacher quality concludes that, teachers' preparation is by far the strongest correlate of student achievement. Teacher experience is another teacher's quality variable that influence students learning. Even though earlier research findings have concluded that relationship between teacher experience and student achievement may not be linear recent research however has documented the importance of teacher experience to student achievement (Cimbriz, 2002).

Darling-Hammond and Sykes (2003) writing on national teachers supply policy for education, the right way to meet the highly qualified teacher challenge concluded that beyond verbal skills, subject matter knowledge and professional knowledge, experience makes an important difference in student learning. Rivkin, Hanushek and Kain (2005) further indicate that "beginning teachers are not as effective as teachers with more years of teaching experience with brand new teachers being the least effective" (p. 449). The point of this discussion about teacher experience is that there is strong evidence to conclude that the amount of experience that a teacher has is beneficial to student achievement.

\section{In-Service Education and Training}

The preparation of teacher for their jobs does not end with their pre-service education at college or university. It is supposed to be a career-long affair. Almost everybody within the teaching profession and beyond it accepts that there is the need for In-service Education and Training (INSET). INSET is closely associated with the idea of continuing education or lifelong education. These concepts underscore the need for all professional people to strive to acquire, on continuous basis, new ideas, skills and attitudes to enhance their competencies and productivity and to effectively cope with inevitable changes that occur in the world of work. Such continuous training and education is considered to be very vital if workers are to stay committed to their vocational ideals, In-Service Education and Training may be likened to the need to maintain a vehicle after it has been used frequently over time just as regularly used and unrepaired vehicle, a teacher who does not participate in INSET long after graduating from college may become stable and perform at a sub-optimal capacity. As ideas methods and ways of doing things change, it becomes necessary for teachers and other professional staff to be reactivated and sensitized to the changes taking place so a that they will be in their position to give of their best.

Several useful definitions have been given to In-Service Education and Training [INSET].many definitions restrict the usage of the term to further training provide to professionals only, though others generalize it to include training of non - professional employees, A UNESCO document explains In-Service Training as "training designed for teachers who are already in professional practice and which they receive in the context of or in the course of their work either off duty time or during period of varying length when their normal duties, are suspended" (UNESCO, 1981). On their part, Harris et al (1969) also say 'In-Service Education is a planned programme of containing learning which provide for the growth of teachers through formal and informal on-thejob experience for all professional personnel definition. 
In-Service training is taken to include all those courses and activities in which as serving teacher may participate for the purpose of extending his professional knowledge, interest or skill. Preparation for a degree, diploma or other qualification subsequent to initial training is included within this definition. Clearly, the foregoing definition limit INSET to training given to only professional personnel. A common wealth regional workshop (Commonwealth, 1977), however defined INSET as: Training that is conducted as any time after an individual has been employed as a full time teacher. Although, less comprehensive in term of describing the characteristic feature of INSET, this definition extends the usage of the term to include training offered to nonprofessional or unqualified teachers and therefore reflects situation as far as INSET in many English speaking African countries are connected. As a matter of fact, in Ghana as in many other Africa countries, INSET has been organized for professional and non-professional teachers in the past. For example, the CPP regime in Ghana, offered a number of INSET courses for pupil-teachers at the Emergency Teacher Training Centres to update their skills to meet the demands of teachers under the Accelerated Development Plan for Education (ADP). Since then a number of workshops and other programmes (including Sandwich Programmes in the Universities) has been organized for untrained teachers to update their skills.

Greenland (1983) surveyed INSET for primary school teachers in English speaking Africa countries and found out that four (4) main types of INSET were provided as Follows;

I. INSET for unqualified teacher

II. INSET to upgrade teachers

III. INSET for new roles

IV. Curriculum-related INSET

INSET for unqualified teachers took place in countries like Nigeria, Zimbabwe, Lesotho, Uganda, Swaziland, Liberia and Sierra Leone. INSET for upgrading teachers took place in countries like Swaziland, Liberia and Nigeria. Nigeria had another variety of this type; ie, INSET for sub-qualified teachers, which was designed to move pupil- teachers who have been given some form of training to higher grade after further training. INSET for new role took place in countries like Ghana, Zimbabwe and Nigeria. In this case, some already qualified teachers were retrained to serve as trainer of trainer or given further training in specialized areas of school life (e.g. giving teacher training in school administration, continuous assessment, or training teachers to serve as guidance and counseling coordinators). Curriculum - related INSET took place in almost all countries. Such INSET was designed to introduce teachers to innovations taking place in the curriculum of schools or to help implement education reforms.

Another approach to analyzing the definitions of INSET is to look at the terminologies that have been used. Some writers prefer to talk about In-Service Training. Others prefer In-Service Education, while yet others combine both training and education. Those who use the term training view INSET as largely concerned with the acquisition of skills and techniques using standardized learning procedures and sequences. The emphasis here is in the acquisition of specific teaching, skills and competencies. The idea here is that typically. INSET programmes are so short to provide for the complete education of participants and that the concentration or form must be directed to the acquisition of know how skills. On the other hand, those who use the term education but as a part of the total frame work of In-Service Education. Those of the second school of thought believe that the acronym INSET is unnecessary as it suggests a false parallel and possibly equal relationship between education and training.

\section{Purpose of Inset}

Many interesting, yet complimentary opinions have been expressed about the purposes of INSET in the literature. For example, Morant, (1981) discusses the purposes of INSET in relation to the needs of teachers under four (4) subheadings, namely, induction needs extension needs, refreshment needs, and conversion needs. These needs incidentally parallel the career life - cycle stages of teachers which create scenarios that call for further training and education.

1. Induction Needs: INSET may be necessitated when a new entrant to the teaching profession takes up his first teaching job after completing college or university. Here emphasis is aced on helping the new teacher to get properly started on his new job and avoiding or coping effectively with the so-called "induction crisis." Such INSET programmes aim at giving the new teacher smooth adjustment to the people, machines, equipment, duties and responsibilities at the workplace. The same kind of INSET may be necessary in a situation where an experienced teacher takes up work in a new untried area, occasioned by promotion to head of department, deputy head teacher, head teacher and the like. Also, a teacher may need to be given INSET when he is transferred to a new school or even to a new class which he was not being teaching before.

2. Extension Needs: In the case a teacher who has served in a particular position in a school for several years and has acquired considerable working experience in that capacity may require to be trained or educated further to widen his professional and academic horizons by relating his presence responsibilities and duties and experienced to wider interest of the education service. 
3. Refreshment Needs: Here emphasis is placed on updating teachers' knowledge and skills learnt in the past. Also, teachers who may have vacated teaching for a while may be given refresher courses and reinvigorated to perform to expectations.

4. Conversion Needs: Teachers transferred to entirely different job in schools for which they have not received any prior preparation, or who are being redeployed within the education service, may be given further training and education to them for their new duties and responsibilities.

Manu (1993) takes a more comprehensive view of purpose served by INSET by expanding it beyond the needs of the teachers for which INSET may be required to include other needs such as the needs of the school and the needs of the entire educational system. He identifies four (4) categories of needs which INSET may be related to viz:

1. Teacher needs

2. $\quad$ System and institutional needs

3. Curriculum implementation and

4. School improvement

Teacher Needs: Manu's teacher need category conceptually response broadly with the whole array of needs discussed by Morant (1981). Specifically, Manu points out that INSET may be necessitate by the desire of the teacher to correct her deficiency or to expand upon existing proficiencies. He also states that INSET allows teachers to expand their knowledge in specific area of study or to learn content of a new subject area. It may also originate from the need for teachers to keep abreast of current educational research or technological developments which imparted on teaching. The provision of such INSET originates from demands for training by the teachers themselves. System and institutional Needs: INSET can be used for implementing changes in educational institutions and the entire educational system. These changes may take the form of implementing a new curriculum or may relate to overall school improvement involving changes in the organizational structure of schools and school climate. Curriculum Implementation: INSET may be used to help modify attitudes, knowledge, skills and behaviour to enhance implementation of new school programmes.

School Implementation: INSET may also be used to enhance system - wide changes in the structure and functions of schools to ensure school improvement. Smith (1969) also states the goals of INSET as follows:

1. To remedy the teachers' deficiencies arising out of defects in his initial teacher training preparation.

2. To advance the teachers skills and pedagogical knowledge required for new teaching roles.

3. To advance and update the teachers knowledge of subject-matter, administrative skills and new trends in curriculum development and

4. To train the teacher for extra-curricular activities

\section{Benefits Associated With INSET}

The benefits offered by INSET includes the following

1. Teachers who participate in INSET programmes require new concepts and practice.

2. INSET programme helps teacher to acquaint themselves with curriculum changes in the school system. For example when a cultural study was introduced into the basic school curriculum, teachers got to know how to handle it through INSET programmes.

3. It encourages teachers to develop and evaluate curriculum materials.

4. It helps to improve teaching and learning methods by equipping trainers with pedagogical skills.

5. Furthermore, it enables teachers to evaluate themselves and to upgrade their professional status.

6. Additionally, INSET provides opportunity for professional to interact in order to share ideas about their works.

7. It also equips new teachers with knowledge and skills to orientate them to their new surroundings and the challenges of their new responsibilities.

8. Lastly, it equips administrative personnel of GES with new and improves leadership skills.

\section{Challenges Teachers Face in the Teaching of Social Studies}

The transaction process in almost every programme is often fraught with challenges. Challenges teachers face may be due to a number of constraints on the ground. In the first place social studies is seen as an integration of concepts and epistemologies from different disciplines which is considered highly desirable as a way of gaining insight and furthering our understanding of a problem. Even though integration is desirable achieving it carrier. Bean (1995) asserts that there is confusion about the actual meaning of curriculum integration since the term is associated with almost any approach that is not strictly based on separate subjects. According to Bean the bone of contention on deliberation about curriculum integration is the fate of the disciplines. In his view the relationship between curriculum integration and the disciplines is easy, but in practice it is problematic. Schott (1996) claims that curriculum integration entails increased bureaucratic, organizational, and behavioural changes 
for successful implementation, for example single subject discipline approach requires very little change in the traditional school structure or in the teacher' lesson plan. Integration means doing something different which in the interim would be difficult as it involves a change in the normal role of the teacher.

It appears a large majority of teachers lack confidence in integration as they have not been oriented to an integrated approach during their pre-service education and have considerable difficulty in adopting it at a later stage of their professional .Concern has also been raised that social studies as an integrated area of study tends to produce superficial coverage over a broad area as opposed to the subject matter approach which emphases depth. The focus upon discipline based studies appears to be gaining momentum with the argument that there is the need for reversion to the teaching of the separate subjects. Repeated criticism of social studies is that its artificial coverage has led to the loss of the consolidation of the separate subjects. Paxton (2003) in an analysis of students" historical knowledge writes "the bulk of evidence suggests that students today know least history as their parents did" (p.41). Hess and Posselt, (2002) in support of single discipline approach also noted "...that if students can be taught how to discuss better [in social studies] is a claim supported by little empirical evidence and virtually none in the recent social studies literature" (p. 284). Recent challenge emanating from the separate discipline approach is based on Bishop (1985) assertion that "teachers are not adequately prepared for change through in-service courses and continue to think in terms of biological, chemical and physical topics as, textbooks, and examination papers continue to reflect the separate disciplines" (p.95).

Bean (1995) an integrated curriculum takes away from teachers their specialist role and so teachers may resent swapping their subject expertise for the right to participate in a generalized approach to human problems and issues. Supporting single subject approach as against integration Leming (2003) argues that "social studies as a vehicle for promoting social change has rested on faulty assumptions about the intellectual capacities of youth and has deflected social studies leaders attention away from the important subject matter in history, geography, economics, and civics as it lacks curricula and effective pedagogy" (p.124). It follows from these arguments that those who advocate separate disciplinary approach see multi-disciplinary knowledge like social studies as subordinating content knowledge and that such a focus has deleterious consequences for social science instruction. An equally important challenge to social studies teaching is the element of time.

Considerable amount of instructional time is a necessary requirement for planning and organizing an integrated programme. In social studies teaching, ample time is needed to identify, formulate objectives and specify the scope and sequence of the content. However, instructional time in basic schools seems to centre on core curriculum of English, mathematics and science with limited attention on social studies. In their inquiry into what elementary school teachers and students say about social studies, Zhao and Hoge, (2005) observed that for decades, social studies in elementary schools has often been regarded as a subject that should be taught, only when there is time. A similar research work by VanFossen, (2005) concluded that priority in the schools is given to basic skill areas of reading, mathematics and language. The effect of the marginalization of social studies is of great concern. Turner, (2004) reducing the amount of time that students are taught in social studies could impact on the quality of social studies education.

Again one major problem confronting social studies is the prevalence Of large class sizes which according to Stanley and Porter, (2002) are often regarded as [italics added] gateway courses to students' major fields of study" (p, xxi). The negative implications of large classes is well articulated by McGregor, Cooper, Smith and Robinson, (2000) who state that "a growing body of research points to the value of learning environment large class settings have historically been heavy lecture centred requiring minimal student engagement and expecting little more than memorization. The large class size seems to militate against students' involvement and intellectual development, inattention or absence from class" (p. 1). It is discernible from the views of McGregor, et al. that large classes encourage the reliance on lecture as well as less students' participation in the teaching learning process. Fassinger, (1996) puts it "because students say that they, as a whole, are even less active in class, the effects of students passivity may be felt more strongly by students" ( $p$ 30). It may be concluded that large classes are not as effective as small class for retention of knowledge and critical thinking.

\section{Research Design}

A research design, Burns, (1997) and Cohen, Manion and Morrison (2000), is essentially a plan illustrating the strategy of investigation by the researcher. In this plan, the kind of data needed, the method used for the data collection, the procedures for obtaining data and data analysis procedures are clearly outlined. I employed quantitative approach. Such a tool, like questionnaire, is vital in obtaining the objective views of Social Studies teachers about the nature of the subject. The rationale for this approach is that, the quantitative data and the subsequent analysis provide a general understanding of the research problem (Creswell, 2003; Tashakkori \& Teddie, (1998). I used the quantitative approach because it has the tendency to bring out the objective views of the respondent on the research problem. Again, it was designed to explore teachers' perception of Social Studies and how they teach the subject at the Junior High School in Berekum Municipality in Brong Ahafo Region of Ghana. Such a tool, questionnaire, is vital in obtaining the objective views of social studies teachers about how 
the perceive the subject.

\section{Population}

The population for this study included all Social Studies teachers in the Junior High Schools in the Berekum Municipality, in the Brong Ahafo Region. According to Cohen, et al (2000), a target population is a group of respondents from whom the researcher is interested in collecting information and drawing conclusions. According to records from the Berekum Municipal Education Service, there are hundred and Twenty-four (124) Social Studies teachers in the Municipality as at September, 2015.

\section{Sample and Sampling Procedure}

The sample size for the study was hundred (100) social studies teachers. The choice of hundred social studies teachers was based on Krejice and Morgan (1970) table for determining sample size from a given population. Purposive sampling procedure was used in the selection of social studies teachers for the study. In determining the number of schools for the study, random sampling technique was used to select twenty-four schools. The reason for selecting Berekum Municipality was due to the cost of travelling and its associated risks to some of the districts in the Brong Ahafo Region.

In all, twenty-four (24) Basic Schools were selected for the study, making a total of hundred (100). See Table 3).

The Table 3 below shows the number of schools selected for the study

\begin{tabular}{lcc}
\hline Name of Junior High school & Number of Teachers & Percentage (\%) \\
\hline Kato R/C junior high school & 5 & 5 \\
BECOLED Demonstration junior high school & 4 & 4 \\
BECOLED Experimental junior high school & 4 & 4 \\
St. Monica's junior high school & 5 & 5 \\
Methodist junior high school & & 5 \\
Koraso L/A junior high school & 4 & 4 \\
Jamdede junior high school & 4 & 4 \\
Kutere No.1 junior high school & 3 & 3 \\
Senase Methodist junior high school & 4 & 4 \\
Mpatasie junior high school & 3 & 3 \\
Jinijini presby junior high school & 4 & 4 \\
Jinijini Methodist junior high school & 3 & 3 \\
Jinijini S.D.A. junior high school & 5 & 5 \\
Fetentaa Methodist junior high school & 4 & 4 \\
Fetentaa R/C junior high school & 4 & 4 \\
Biadan R/C junior high school & 4 & 4 \\
St. Augustine junior high school & 4 & 4 \\
Kato Presby junior high school & 4 & 4 \\
Mpatapo R/C junior high school & 4 & 4 \\
Botokrom L/A JHS & 4 & 4 \\
Botokrom Methodist JHS & 4 & 4 \\
St. Lucy JHS- Jinijini & 4 & 4 \\
\hline TOTAL & $\mathbf{1 0 0}$ & $\mathbf{1 0 0}$ \\
\hline
\end{tabular}

Source: field study, 2021

The table 3 above shows the number of schools and respondents (social studies teachers) used for the study. Hundred (100) teachers were selected from the Junior High Schools in Berekum Municipality, Brong Ahafo Region, Ghana

\section{Pilot study}

A pilot study was conducted with Social Studies teachers who graduated from the Colleges of Education to establish validity and reliability of the instrument. The researcher selected twenty (20) Social Studies teachers from five (5) schools in Berekum, Brong Ahafo Region. It was done through a purposive sampling technique. The study was about teachers who teach Social Studies at the Basic schools. The questionnaire has Twentyseven (27) items (Six demographic, six internship, ten nature of Social Studies and five teaching skills) all were open-ended question. Schools were randomly selected from Berekum Municipality and teachers were asked to fill out the survey. 


\section{Validity}

To enhance the validity in the study, I first discussed the questionnaire with my colleagues in Berekum College of Education, and then I showed it to some lectures of Social Studies Department, University of Education, Winneba. The questionnaire was finally given to the supervisor for the necessary corrections and was reframed. The instrument really measures the perceptions of Social Studies teachers in terms of their internship, nature of Social Studies and teacher skills. Social Studies teachers responded to the questionnaire which was in the form of Likert- type scale, and from its deductions were made from the scores.

\section{Reliability}

Airasian, (2003), reliability is the degree to which a test consistently measures whatever it is measuring. An instrument can thus be said to be reliable if it is shown to provide consistent scores if the survey is repeated on the same population. It was clear from the SPSS data analysis that the positive responses to the questionnaire exceeded $70 \%$. Therefore, I can conclude that the results are reliable because it exceeds the standards called for in the Social Studies literature. Nunnally, (1978), has suggested that score reliability of 0.7 or better is accepted when used in basic Social Science Research.

\section{How the pilot test data was administered and collected.}

I, went to selected Junior High schools in the Berekum Municipality, after seeking permission from the various Heads, the questionnaire were given to the Social studies teachers to respond to. All participants were asked to complete the questionnaire and they were assured anonymity and confidentiality. I went to the heads for the completed questionnaire.

\section{Result of the study}

The outcome of the pilot study was of great help to me. It opened up some weaknesses in the framing of some of the questions which could have easily distracted the meaning of some of the items. Suggestions from teachers, who responded to the questionnaire, helped me to modify some of the items that were not clear. This helped in the arrival of final instrument which was used for the study. Simple percentages were used to administer each teacher's view about their perception of social studies to test for validity and reliability of the instrument.

\section{Procedure for data collection of the pilot study at Berekum Municipality}

The administration of the instrument started in $9^{\text {th }}$ February, 2015. An introductory letter was obtained from the Principal of Berekum College of Education, to facilitate the administration of the questionnaire. A copy of the letter was attached to the questionnaire which helped me to have the necessary assistance and cooperation from the social studies teachers from the selected Basic Schools. I selected twenty (20) social studies teachers from Five (5) Basic Schools in Berekum Municipality for the pilot study. With the permission of the Headmasters, social studies teachers were briefed on the objective of the study and were given a week to complete the questionnaire.

\section{Instruments for Data Collection}

The researcher used the following instruments in gathering data: A questionnaire made up of forty (40) closeended four-point Likert Scale Structured items were administered to hundred (100) Social Studies teachers in the selected twenty-four (24) Junior High Schools in Berekum Municipality. The following point values are assigned to positive statements; Strongly Agree $(\mathrm{SA}=4)$, Agree $(\mathrm{A}=3)$, Disagree $(\mathrm{D}=2)$, and Strongly Disagree $(\mathrm{SD}=1)$. The questionnaire is divided into Sections (Parts A to G). Part ' $A$ ' consisted of demographic information such as sex of teacher, qualification, and age. Part ' $B$ ' contained four items used to elicit information on the meaning of Social Studies. Part 'C', which contained four (4) items, elicits information on academic qualification of Social Studies teachers. Part ' $D$ ' which was on Scope and Goals of Social Studies contained five (5) items. Part 'E' contained four (4) items on Social Studies internship programme, during out- programme segment. Part ' $F$ ' was used to elicit information on the nature of Social Studies education at the Junior High Schools; it consisted of ten (10) items. Part ' $G$ ' which is the last part contained nine (9) items which was on the techniques of teaching Social Studies at the JHS

The questionnaire which was the main research instrument was scrutinized and accepted by the supervisor before it was administered. Before collecting the data, a copy of the thesis proposal was submitted to the Department of Social Studies, University of Education, Winneba for approval. After obtaining an approval, an introductory letter (see Appendix) was given to me. This was to enable me seek permission from the various heads of the junior high schools in Berekum Municipality, in order to carry on with the study. Three weeks were used to collect the questionnaire. These were $2^{\text {nd }}-6^{\text {th }}, 9$ th $-13^{\text {th }}$ and $16^{\text {th }}-20^{\text {th }}$ of March, 2015. The ample time used yielded a positive result, out of the one hundred and twenty questionnaires administered hundred (100) were retrieved. The retrieval rate of $96.7 \%$ is very remarkable in research of this nature. 


\section{Data Analysis of the Main Study}

The quantitative data entry and analysis was done by using the Statistical package for Social Sciences (SPSS) software. I edited the data collected through questionnaire to help ensure that all the information gathered was ready to be used. This was followed by coding to make the data be analyzed by the use of the SPSS software into tables and percentages. Lastly, I used descriptive statistic to interpret the data.

\section{Descriptive Analysis Using One Sample Mean T-test}

The one sample mean t-test is used to ascertain the relative significance of the variables. For a single sample test, the hypothesis is set as Ho: $\mathrm{U}=\mathrm{Uo}$ and Ha: U\# Uo. With Ho representing the null hypothesis indicating that there is no significant difference between the means, Ha representing the alternative hypothesis indicating there is a significant difference between the means and Uo representing the hypothesized mean. A statistical test of the mean was done to decide whether the population considered a particular variable to be important or not. For each variable, the null hypothesis was that, this variable was not significant (Ho: $\mathrm{U}=\mathrm{Uo}$ ) indicating there is no significant difference between the means. The Uo is the critical rating above which the variable is considered important. The Likert scale was, $1=$ strongly disagree, 2 -disagree, $3=$ not sure, $4=$ agree and $5=$ strongly agree. Under this section, the lower ratings of 1 and 2 were chosen for the rating scale as strongly agree and agree respectively while the Uo was set at 2.0 , with $95 \%$ as the significance level in accordance with the antecedent. This premised on the five point Likert scale rating where a success variable is deemed important if its probability value is less than 0.05 .

\section{Meaning of Social Studies}

Chi-Square Goodness of Fit Test indicating whether the definition of Social Studies varies from Country to Country

Table 4: Chi-square goodness of fit table indicating whether definition of social studies varies from The Definition of Social Studies Varies from Country to Country

\begin{tabular}{|l|c|c|c|c|c|c|}
\hline Response & \multicolumn{2}{l|}{ Observed N Expected N Resident DF Chi-square Value P- } & \multirow{2}{*}{} \\
\cline { 1 - 5 } $\begin{array}{l}\text { Value } \\
\text { True }\end{array}$ & 51 & 50.0 & 22.0 & 11 & 6.040 & 0.000 \\
\cline { 1 - 3 } & 49 & 50.0 & -22.0 & & & \\
\hline
\end{tabular}

country to country

Total 100

Source: Field work, 2021

The Chi-square goodness of fit table above gives statistics on whether the definitions of social studies vary from country to country. The result from the table reveals that fifty-one (51) respondents representing $51.0 \%$ of the total population said really it is true that the definition of social studies varies from country to country whereas only 49 respondents representing $49.0 \%$ were in view that, the definition of social studies does not vary from country to country.

The Chi-square goodness of fit test results indicated from the table above that, there is a significant difference between the observed and the expected frequencies of response from the respondents involved in the research work ( i.e. p-value $=0.000<0.05$ ). This as a result confirms that, the definition of social studies varies from country to country. This confirms Aggarwal (1992) assertion that the term 'Social Studies' has been defined differently by different commission, committees and writers. The situation is not good for the teaching of the subject, because teachers are divided as to whether social studies has a universal definition or not. This brings to sharp focus the research question 'what do social studies teachers think about the subject', their perception about the subject is based on their understanding of the social studies curriculum. Whatever angle one looks it from, social studies education is designed to help solved societal problems.

Chi-squares goodness of fit test indicating whether the Social Studies is seen as Citizenship Education in Ghanaian Schools Social Studies seen as Citizenship Education in Ghanaian Schools

Table 5: Chi-square goodness of fit table indicating whether social studies is seen as Citizenship Education in Ghanaian Schools

\begin{tabular}{lcccc}
\hline $\begin{array}{l}\text { Response } \\
\text { Value }\end{array}$ & Observed N & Expected N & Residual DF & Chi-square P- Value \\
\hline Yes & & & 26.01 & 27.0400 .000 \\
No & 76 & 50.0 & -26.0 & \\
\hline Total & 24 & 50.0 & & \\
\hline
\end{tabular}

Source: Field work, 2021 
Table 5 above gives information about whether social studies is seen as citizenship education in Ghanaian schools. The data indicate that majority of the respondents confirm really that social studies is seen as citizenship education in Ghanaian schools. The results from the data reveals that, seventy-six (76) respondents, representing $76.0 \%$ of the total population were of the view that social studies is seen as citizenship education in Ghanaian schools while only twenty-four (24) respondents representing $24.0 \%$ on the other hand were of the view that social studies is not seen as citizenship education in Ghanaian schools. The Chi-square goodness of fit test gives a $\mathrm{p}$-value less than level of significance 0.05 ( $\mathrm{p}$-value $=0.011<0.05$ ) which as a result indicates that there is a significant difference between the observed and the expected frequencies of the response categories. The test therefore confirms that really social studies is seen as citizenship education in Ghanaian schools.

This is consistent with Banks (1990) assertion that citizenship education is the primary focus of social studies in the school curriculum which promotes desirable participatory citizenship and further confirmed by the position of Bar and Shermis (1977) that social studies is an integration of experience concerning human relations for the purpose of citizenship education. Tamakloe (1994) opines that Social Studies places premium on individual qualities such as patriotism, honesty, diligence, obedience and critical thinking and also group ideas like interdependence, co-operation and peaceful coexistence.

Chi-square Goodness of Fit test Indicating Whether Social Studies is the Study of Man and His Environment.

Social Studies is the Study of Man and His Environment

Table 6: Chi-square goodness of fit table indicating whether social studies is the study of man and his environment.

\begin{tabular}{lccccc}
\hline $\begin{array}{l}\text { Response } \\
\text { Value }\end{array}$ & Observed N & Expected N & Residual & DF & $\begin{array}{c}\text { Chi-square P- } \\
\text { Value }\end{array}$ \\
\hline Yes & 75 & 60.0 & 29.0 & 1 & 28.033 \\
No & 25 & 60.0 & -29.0 & & 0.000 \\
\hline Total & 100 & & & & \\
\hline
\end{tabular}

Source: Field work, 2021.

The Chi-square goodness of fit table above gives statistics on whether social studies is the study of man and his environment. The result from the table reveals that seventy-five (75) respondents representing $75.0 \%$ of the total population responded 'Yes' indicating that social studies is the study of man and his environment whilst the remaining twenty-five (25) respondents also representing $25.0 \%$ were in the view that social studies is not the study of man and his environment. The table additionally indicates that, there is a significant difference between the observed and expected frequencies of response since the p-value is less than the level of significance 0.05 . This as a result confirms that social studies is the study of man and his environment. This position is found in Tamakloe, (1994) suggestion that, social studies is a subject that deals with man and his relationship to his environment. The data show that those social studies teachers are aware that the environment should be protected and sustained. Therefore, they are likely to place emphasis on topics that talk about how to sustain the environment using practical examples from the learners' community.

Chi-Squares Goodness of Fit Test on Whether Social Studies is an Approach of Teaching Social Sciences. Table 7: Chi-square goodness of fit table indicating the response from respondents as to whether social studies is an approach of teaching social sciences.

Social Studies as an Approach of Teaching Social Science

\begin{tabular}{lcccccc}
$\begin{array}{l}\text { Response } \\
\text { Value }\end{array}$ & Observed N & Expected N & Residual & DF & \multicolumn{2}{l}{$\begin{array}{l}\text { Chi-square P- } \\
\text { Value }\end{array}$} \\
\hline Yes & 87 & 50.0 & 37.0 & 1 & 4.760 & 0.000 \\
No & 13 & 50.0 & -37.0 & & & \\
\hline Total & 100 & & & &
\end{tabular}

Source: Field work, 2021.

The Chi-square goodness of fit table above gives information as to whether respondents see social studies as an approach of teaching social sciences. The results from the table reveals that, eighty-seven (87) respondents, representing $87.0 \%$ of the total population were in view that, social studies is an approach of teaching social sciences whilst $13.0 \%$ of the respondents, representing 13 out of 100 respondents were in the view that social studies is not an approach of teaching social sciences. The table additional shows a significant difference between the observed and expected frequencies of responses from the respondents involved in the research work since the P-value $(0.000)$ is less than the level of significance 0.05 . This therefore confirms that really social 
studies is an approach of teaching social sciences. Linguist, (1995) and Martorella (1994) position that the role of the social sciences which provide the base for social studies teaching.

\section{Perception of Teachers about the Nature of Social Studies}

Nature of Social Studies Education

Sig.

Table 8: One Sample Mean Test Table on Nature of Social Studies Education

Test Value $=2.5$

Mean

$\mathrm{T}$

(2-tailed)

\begin{tabular}{|c|c|c|c|c|}
\hline $\begin{array}{l}\text { Social Studies Education is relevant to the needs of Ghanaian Society } \\
\text { Social Studies Education is a citizenship education }\end{array}$ & 1.8851 & -6.319 & .031 & $\begin{array}{l}-61494 \\
-\end{array}$ \\
\hline Social Studies Education & 1.9885 & -5.488 & 0.209 & .51149 \\
\hline $\begin{array}{l}\text { problems } \\
\text { Social studies Education is well designed to suit the needs of pupils }\end{array}$ & 2.0000 & -4.835 & 0.001 & .50000 \\
\hline & 2.0690 & -4.128 & 0.468 & .43103 \\
\hline Social Studies Educa & 2.0805 & -4.324 & 0.000 & \\
\hline Social Studies Educatio & 2.0920 & -4.438 & 0.000 & $\begin{array}{l}- \\
.40805\end{array}$ \\
\hline Social Studies Education can be taught by a single subject specialist & 2.1059 & -4.037 & 0.000 & $\begin{array}{l}- \\
.39412\end{array}$ \\
\hline $\begin{array}{l}\text { Social Studies Education is the study of ourselves and our } \\
\text { environment }\end{array}$ & 2.1379 & -4.329 & 0.000 & -36207 \\
\hline $\begin{array}{l}\text { Social Studies Education helps to appreciate the impact of history in } \\
\text { current and future development effort of the country } \\
\text { Social Studies education helps in the development of positive } \\
\text { attitudes, values and skills. }\end{array}$ & 2.2529 & $\begin{array}{l}-2.796 \\
- \\
.2 .267\end{array}$ & 0.000 & $\begin{array}{l}- \\
.24713 \\
- \\
.21264\end{array}$ \\
\hline
\end{tabular}

\section{Source: Field work, 2021}

The study showed that all the items accounted for the nature of social studies. Ten (10) items were given to respondents to choose from, of which none of them had their mean above the hypothesized mean of 2.5. The one sample mean t-test value for all the 10 items or variables were negative which gives an indication that all the items had a mean below 2.5. However, out of the ten (10) items assumed to be a nature of social studies, eight (8) items were statistically significant since their p-value were less than 0.05 with only two (2) being insignificant. This result gives an indication that, the items social studies education is relevant to the needs of Ghanaian society. Social Studies education provides practical approach in solving problems; Social studies education addresses societal problems. Social Studies education is integration of subjects, social studies education can be taught by a single subject specialist, social studies education is the study of ourselves and our environment, Social studies education helps to appreciate the impact of history in current and future development effort of the country and Social studies education helps in the development of positive attitudes, values and skills can be confirmed as the nature of social studies. There is in line with the position of the Ghana Education Service (2001) that Social Studies is Citizenship Education; the subject tries to prepare the individual to fit into society by6 equipping him/her with the kinds of knowledge, skills, values and attitudes needed for effective living within the society and for making constructive changes in the way of life of society.

\section{The Techniques of Teaching Social Studies at the JHS}

With respect to the techniques of teaching social studies, respondents involved on the study were asked to indicate how frequent they use some methods when it comes the teaching of social studies. As depicted in the table below, respondents involved in the study cited how frequently they respectively employ some methods or techniques in teaching social studies.

Techniques of Teaching Social Studies 
Table 8s: Frequency Table on the Techniques that Suits the Teaching of Social Studies

\begin{tabular}{lcrrc}
\hline Frequency & Not at all & Sometimes & Frequently & Always Lecture 0 \\
& 7 & 63 & 30 & \\
\hline Brainstorming & 0 & 57 & 43 & 0 \\
Role play & 4 & 60 & 23 & 13 \\
Discussion & 4 & 33 & 45 & 18 \\
Field trip & 21 & 62 & 14 & 3 \\
Resource person & 20 & 59 & 16 & 5 \\
Simulation & 11 & 55 & 28 & 6 \\
Debate & 5 & 75 & 16 & 4 \\
Question and Answer 3 & & 4 & 37 & 56 \\
\hline
\end{tabular}

\section{Source: Field work, 2021}

The table indicated above therefore depicts that out of the 100 respondents seven (7) indicated they do not use lecturing as a technique of teaching social studies at all, sixty- three (63) respondents on the other hand said they sometimes use lecturing as a technique of teaching social studies whilst the remaining thirty (30) respondents stated that they frequently use lecturing as a technique of teaching social studies. This therefore gives the indication that lecturing is not always a technique used by teachers in the teaching of social studies. Also, with respect to brainstorming as a technique of teaching social studies, none of the respondents indicated it as a technique of teaching either not at all or always. Rather 67 respondents said they sometimes use it as a technique of teaching social studies whilst the remaining 43 stated they frequently use it as a technique of teaching the subject.

In addition to the above mentioned technique, only four (4) out of the 100 respondents responded that they do not use role play as a technique for teaching social studies at all, thirty-three (33) respondents also said they sometimes use it as a technique of teaching social studies whilst 45 respondents opted that, they frequently use role play as a technique of teaching social studies with the remaining eighteen (18) respondents using role play always as a technique or method of teaching social studies. Only four (4) other respondents out of the 100 respondents involved in the study stated that, discussion is not a technique they use in teaching social studies at all, thirty- three(33) on the other hand made the statement that discussion as a technique of teaching social studies is what they sometimes use whilst forty-five (45) respondents said they frequently use discussion as a technique of teaching social studies with the remaining 18 respondents always using discussion as a technique of teaching the subject.

In addition, out of the 100 respondents who responded to field trip as a technique of teaching social studies, twenty-one (21) responded this is a technique of teaching social studies they don't use at all. A maximum of 62 respondents also said that they use field trip as a technique of teaching social studies sometimes whilst fourteen (14) respondents stated that they use this technique frequently. Only three (3) of the 100 respondents involved in the research work responded they always use field trip as a technique of teaching social studies.

According to the respondents who responded to the technique "resource person" as a technique of teaching social studies, twenty (20) out of the 100 respondents accepted the fact they have not at all used resource person as a technique of teaching social studies, 59 respondents indicated they sometimes use it as a technique of teaching whilst sixteen respondents said they have frequently used resource person as a technique of teaching social studies. Only five (5) respondents out of the 100 respondents stated that they have always been using resource person as a technique of teaching social studies.

Among the number of respondents who responded to simulation as a technique of teaching social studies, only eleven (11) made the statement that they never used this method under discussion as technique of teaching social studies, fifty-five (55) respondents on the other hand, made it known that simulation is a technique of teaching they sometimes use in teaching social studies whilst twenty-eight (28) respondents said this a technique they have frequently been using when it comes to teaching social studies. The remaining six (6) respondents chose always as the extent to which they use simulation as a technique of teaching social studies. Last but not the least, according to the responses from the 100 respondents involved in the research work with respect to the technique debate, Five (5) respondents indicated that they have never used this technique in teaching social studies, seventy-five (75) also said they have been frequently using simulation as a suitable technique of teaching social studies whilst sixteen (16) on the other hand said simulation is a technique they have been using to teach social studies frequently with the remaining four (4) respondents indication that have always been using simulation as a method of teaching social studies.

Finally, from the above frequency table, with respect to the technique "question and answer" only three (3) respondents stated that they have not at all used it as a technique of teaching social studies, four (4) respondents also said they sometimes use question and answer as a technique of teaching social studies whilst thirty-seven (37) out of 100 respondents involved in this research work chose frequently as the extent to which they have 
been using question and answer as a technique of teaching social studies. In all fifty-six (56) respondents said questions and answers is the technique they have always been using when it comes technique used in teaching social studies.

The above statistics in summary indicates that among the suggested techniques for teaching social studies, questions and answers is the technique most teachers always use in teaching social studies, followed by discussion. This is embraced in the position of the African Social and Environment Studies Programme (1990) lists of 150 techniques of teaching social studies.

The Nature and Purpose of Social Studies in JHS Table 9s: Scope and Goals of Social Studies Test Value $=2.5$ Scope and Goals of Social Studies

The scope of social studies is limited to social sciences

The mean goal of social studies is to promote citizenship education

Social studies is seen as a broad umbrella that covers a range of subject discipline and skills The most important aspect of teaching social studies is cognitive domain Social studies syllabus is overloaded

\begin{tabular}{l|c|c|c}
\hline Mean & $\boldsymbol{T}$ & $\begin{array}{l}\text { Sig. } \\
\text { (2-tailed) }\end{array}$ & $\begin{array}{l}\text { Mean } \\
\text { Difference }\end{array}$ \\
1.45 & -5.347 & 0.000 & -0.500 \\
1.81 & -2.046 & 0.043 & -0.190 \\
2.38 & 6.730 & & 0.380 \\
1.81 & & 0.000 & \\
2.07 & -2.690 & 0.00 & -0.190 \\
& 0.969 & 0.445 & 0.070
\end{tabular}

\section{Source: Field work, 2021}

With respect to the scope and goals of social studies, five (5) items were used, of which all had the mean within the acceptable range (less than 2.5 ). The above t-test table revealed that among the five variables used as scope and goals of social studies only "social studies syllabus is overloaded" was not significant indicating that the syllabus of social studies being overloaded cannot be a scope and a goal of social studies. The result from the table 13 therefore shows that the variables social studies is limited to social sciences, social studies is to promote citizenship education, social studies is seen as a broad umbrella that covers a range of subject discipline and skills and social studies is cognitive domain are the scope and goals of social studies since they are significant (p-value $<0.05$ ). This underpins Ross and Marker, (2005) opinion that, the purpose of social studies is citizenship education aimed at providing students opportunities for an examination, critique and revision of the past traditions, existing social practices and model of problem-solving.

The Significance of In-Service Training in Social Studies Education

Table 10: Chi-square Goodness of fit test indicating whether respondents do attend in-service training

Attending In-Service Training

\begin{tabular}{|c|c|c|c|c|c|}
\hline Response & Observed N & Expected N & 'nesidual & DF Chi-square Value & P-value \\
\hline Yes & 66 & 50.0 & 16.0 & $\begin{array}{ll}1 & 10.240\end{array}$ & 0.001 \\
\hline No & 34 & 50.0 & -16.0 & & \\
\hline Total & 100 & & & & \\
\hline
\end{tabular}

Source: Field work, 2021

The Chi-square goodness fit table above gives statistics on whether respondents do- attend in-service training. The result from the table reveals that majority of the respondents representing $66.0 \%$ of the total population involved in the research work agreed that teachers do attend in-service training whilst thirty-four (34) of the respondents, representing $34.0 \%$ were in the view that, teachers do not attend in-service

training. The Chi-square goodness of fit test shows that, there is a significant difference between the observed and expected frequencies since the p-value (0.001) is less than the level of significance $(0.05)$. This as a result confirms that teachers do attend in-service training.

Key: SA-Strongly Agree; A-Agree; D-Disagree, SD -Strongly Disagree 
Table 11: Purpose of Social Studies In-Service Training

\begin{tabular}{|c|c|c|c|c|}
\hline \multirow{2}{*}{ Statements } & \multicolumn{4}{|c|}{ Frequency } \\
\hline & $\boldsymbol{S A}$ & $\boldsymbol{A}$ & 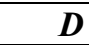 & SD \\
\hline Social studies internship has offered adequate teacher support & 19 & 51 & 17 & 13 \\
\hline $\begin{array}{l}\text { Social studies internship has provided adequate opportunities for feedback on my } \\
\text { performance }\end{array}$ & 12 & 62 & 26 & 0 \\
\hline Social studies internship has linked to classroom practice and theory & 11 & 80 & 9 & 0 \\
\hline Social studies internship has offered opportunity to acquire new teaching skills & 0 & 46 & 54 & 0 \\
\hline
\end{tabular}

Source: Field work, 2021

The frequency table above generally shows the extent to which respondents agree with statements on what social studies internship has offered or provided. The frequency table therefore indicates that, out of the 100 respondents captured in the research work, nineteen (19) strongly agreed that social studies internship has offered adequate teacher support, fifty-one (51) on the other hand agreed to the same statement whilst seventeen (17) respondents, disagreed to the same statement indication that social studies internship has not offered adequate teacher support. The remaining thirteen (13) respondents also strongly disagreed.

In addition, out of the 100 respondents who responded to the statement "Social Studies

Internship has provided adequate opportunities for feedback on my performance", only

twelve (12) respondents strongly agreed that really social studies internship has

provided adequate opportunities for feedback on the performance of teachers whilst sixty-two (62) respondents agreed to the same statement with the remaining 26 disagreeing to the same statement. None of the 100 respondents strongly disagreed to the statement under discussion.

Furthermore, eleven (11) respondents out of 100 strongly agreed that Social Studies internship has linked to classroom practice and theory whilst only eighty $(80)$ respondents agreed to the same statement with the remaining nine (9) respondents disagreeing with the notion that social studies internship has not linked to classroom practice and theory.

Lastly, with respect to the statement "Social Studies internship has offered opportunity to acquire new teaching skills" forty-six (46) respondents agreed indicating that really social studies internship has offered opportunity to acquire new skills whilst the remaining fifty-four (54) respondents disagreed with none of the respondents strongly agreeing or strongly disagreeing with the statement at hand

\section{Summary of the Study}

The study investigated the perception of Social Studies teachers in the Junior High Schools in the Berekum Municipality, Brong Ahafo Region of Ghana. The study sought to provide an empirical basis for the background knowledge of Social Studies teachers and how they teach the subject at the Junior High School. The objective of the study was to find out the perception of social studies teachers on the nature of social studies, techniques for teaching social studies, nature and purpose of social studies and the significance in-services training in social studies. To obtain the sample for the study, the purposive sampling technique was used to select 100 social studies teachers. Descriptive statistics were used to analyze the data collected using SSPS (version 20.0) as a tool. The literature suggests that, the nature of social studies is more of citizenship education. The techniques for teaching social studies include lecture, role play, discussion, field trip, question and answer among others. Nature and purpose of social studies is more of developing positive attitudes, values and skills of the citizenry. Also the significance of in-services training in social studies has offered opportunity for teachers to acquire new teaching skills, from the analysis of the data collected;

\section{Perception of teachers about the nature of Social Studies}

The study established that teachers were homogenous in their assertion that the nature of social studies is that of citizenship education. This is consistent with Banks, (1990) that citizenship education is the primary focus of social studies in the school curriculum which promotes desirable participatory citizenship and further confirmed by the position of Bar and Shermis, (1977) that social studies is an integration of experience concerning human relations for the purpose of citizenship education. The majority of the social studies that were involved in the studies in Berekum Municipality think Social Studies Curriculum is to prepare young learners to become good citizens.

\section{The Techniques of Teaching Social Studies at the JHS}

The study brought to the fore that, teachers' use of questions and answers was within standard. Meanwhile, 'Discussion' and 'Role play' were also accepted as techniques of teaching social studies by respondents. It came to light that Social Studies teachers in Berekum Municipality did not well appreciated the techniques fieldtrip, resource person and simulation. The reason is that about twenty (20) percent of them had never used, the three techniques namely; fieldtrip, resource person and simulation, in their lessons. In spite of this, Social Studies 
teachers in Berekum Municipality employ different teaching technique in the classroom. The varieties of employ by social studies teachers make social studies practical and meaningful, according to the field studies.

\section{The Nature and Purpose of Social Studies in JHS}

The study unearthed that Social Studies Education is relevant to the needs of the Ghanaian society and that Social Studies Education is gear towards citizenship education. Specifically, developing of positive attitudes, values and skills were apt as a purpose of social studies. From the syllabus it appears the incorporation of knowledge, skills value and attitudes are essential to the development of a holistic understanding of social studies. Disciplinary knowledge, used by students to construct learning is drawn primarily from geography, history economic and civic education by integrating them to create the subject social studies. The implication is that the teacher should possess the skills to integrate knowledge effectively by adopting a holistic approach to the teaching of social studies and at the same time maintains a focus on the subject matter. This is what Lucan (1981) calls "integration while preserving discipline identification" (p.63). Social Studies teachers in Berekum Municipality see the subject as such and use various forms of integration (content and method) in their lesson delivery.

\section{The Significance of In-Service Training in Social Studies Education}

The study established that Social Studies in-service offers adequate teacher support. Thus, social studies inservice provides adequate opportunities for feedback on teachers' performance. Adentwi, (2005) heights the benefits of INSET to a teacher; teachers acquaint themselves with curriculum changes, acquire new concepts and practice, and help to improve teaching and learning methods by equipping trainers with pedagogical skills. The studies show that Social Studies teachers in Berekum Municipality do attend INSET. The results from the questionnaire reveals that majority of the respondents representing $66 \%$ of the teachers do attend INSET regularly. This has helped them to teach in accordance with the content and method of teaching social studies at the JHS.

\section{Conclusions}

Largely, teachers perceive that the nature of social studies is that of citizenship education. This explains the reason social studies teachers use techniques such as role play, simulation, debate and discussion in teaching the subject. 'Citizenship education is a subject that aims at producing competent, reflective ,concerned and participatory citizens who will contribute to the development of the communities and country in the spirit of patriotism and democracy'(citizenship education syllabus,2007).Therefore such techniques will have positive impact on the learner, if the techniques are purposefully. Generally, teachers' use questions and answers in teaching social studies. Of all the teaching techniques selected for the study, the majority of social studies teachers, use questions and answers technique a lot more than others. The studies reveal that about ninety-three (93) percent of the teachers use questions and answers frequently and always. Since social studies teachers resort to the use of this technique, other techniques are deemphasized. It rather sharpens learners thinking abilities but impaired motor skills. Largely, the purpose of social studies is to develop positive attitudes, values and skills of pupils. Generally, teachers' opine that Social Studies In-service training offers adequate teacher support.

\section{Recommendations}

Based on the conclusions, it is recommended that teachers continue to acquire relevant knowledge on making Social Studies more relevant to the needs of the citizenry and abreast themselves with teaching techniques that would enhance practical ways of learning and encourage the application of real-life situation. The Ghana Education Service and Managers at the Unit level of schools must improve on organizing in-service training, workshops and refreshable programmes to help enhance Social Studies teachers on the contemporary teaching of Social Studies. It is recommended that further research be conducted to- bring to open the standpoint of pupils on the teaching and learning of social studies.

The research findings identified different schools of thought and the broad scope of Social Studies was a great concern to Social Studies teachers. It is therefore highly suggested that the designers of the curriculum should limit the scope and also have a second look at the different schools of thought about Social Studies. The research findings of the results indicated that Social Studies teachers in the Junior High School face a challenge of embarking on fieldtrip. The study suggests that Social Studies teachers should be given enough motivation and logistics to encourage them to take pupils out to see natural phenomena

\section{Suggestions for further research}

The research which took place in the Berekum Municipality in the Brong Ahafo of Ghana is not representative enough for the whole region in particular and the country at large. Therefore, it is recommended that a similar study should be conducted in the whole Region and other parts of the country in order to make valid 
generalization.

Acknowledgements: Grace Afua Dua Asante and Augustine Adjei, the Dean of Students' Affairs at Offinso College of Education for assisting in data collection, data analyses, write up and editing final work and putting the final paper together.

References

Abdul-Kadiri, H, (1994). Issues in social studies education. The nature of integrated social studies and pedagogical implications. Accra Blackmask Ltd.

Adler, P. A., \& Adle, P. (1998). Observational techniques in collecting and interpreting quantitative materials. California: Sage Publications Inc.

Adentwi K. I (2005) Principle, practices and issues in teacher education. Kumasi: Cubic Osono Press.

African Social and Environmental Studies Programme (ASESP, 1990). Social Studies Curriculum and Teaching Resources Book for Africa. Nairobi: ASESP.

African Social and Environmental Studies Programme (ADESP) (1992). Social and Environmental Studies Programme (ADESP) (1992). Social studies curriculum and teaching resources book for Africa. Nairobi; ASESP.

African Social Studies Programme (1990). Curriculum and teaching resource book for Africa. Nairobi.

Aggarwal, J. C. (1982). Teaching social studies. New Delhi: Vikas Publishing House.

Aggarwal, J. C. (2006). Teaching of Social Studies: A practical Approach $\left(4^{\text {th }}\right.$ ed). New Delhi: Vikas Publishing House PVT Ltd.

Anderson, D.B. \& Pisciteli, B. (2000). Parental recollection of childhood Museum visits. Museum National 10 (4).26-27)

Asiedu-Akrofi, K. (1978). School organization in modern Africa. Tema: Ghana Publishing Corporation.

Airasian, G. P (2003). Research competencies for analysis and applications. Mermil Prentice Halll.

Gay, 1, Mills. G, \& Airasian, P. (2006). How to design and evaluate research in education (5 ${ }^{\text {th }}$ ed). New York: McGraw Hill.

Ayaaba, D. A. (2011). Foundations of Social Studies: An Introduction. Accra: Salt \& Light Publishing.

Ayaaba, D. A. \& Odumah, L. K. (2013). Skills and techniques of teaching social studies (2 ${ }^{\text {nd }}$ ed.). Accra: Salt and Light Publishing.

Banks, J. L. (1990). Teaching strategies for the social studies inquiry valuing and decision making. New York: Longman.

Barr, R. D., Barth, J., \& Shermis, S.S. (1977). Defining the social studies. Bulleting 51. Washington D.C: National Council for Social Studies.

Blege, W. (2001). Social studies: Theory andpractical. Accra: Wallyblege Publication.

Bligh, D. (2002). What is the use of lectures? San Francisco: Jossey Bass.

Bloom, B. S. (1956): Taxonomy of educational research an introduction. $\left(4^{\text {th }}\right.$ Ed).

New York: Longman W.C.

Bruce, R. K. (1988). The teaching of social studies in junior high schools. (Unpublished Manuscript).

Bruce, R. K. (1975). The Upper Dichem Valley (Ghana). In Evans KM (Ed).

Social Studies in practice. London and Basingstoke: Macmillan Education Ltd.

Bryman, A. (2004). Social research methods $\left(2^{\text {nd }} \boldsymbol{E d}\right)$. New York: Oxford University Press Inc.

Casely-Hayford, L. (2007). Recoup working paper No. 8 gendered experiences of

teaching in poor rural areas of Ghana. Social Development Consultant, Associates for Change (AFC) 11, Adabraka Subukwe Close, London: Routledge (In Press).

Cimbricz, S (2002): State mandated teaching and teachers beliefs and practices

education policy analysis archives ID (2). Retrieved on July, 26, 2012. from http://www.epaa.asu.edu/. 10(1)

Clark, L.H. (1973). Teaching social studies in elementary schools. A handbook for teachers' college. New York: Macmillan Publishers. Nt. Co. Inc.

Cobbold, C. (1999). The implementation of social studies in the training colleges,

Ghana: An evaluation. Unpublished Master's Thesis. University of Cape Coast, Cape Coast.

Creswell, J.W. (2003). Research design: Qualitative, quantitative and mixed methods approaches (2 ed.).Thousand Oaks: Sage Publication.

Darling-Hammond, L. (1997). Doing what matters most: Investing in quality teaching. New York: National Commission on Teaching and America's Future.

Darling-Hammond, L. (2000): Teacher quality and students achievement education policy analysis archives. Retrieved July 13, 2012. http://www.epaa.asu.eduZ. 8 (1) "

Darling-Hammond, L. \& Sykes, G. (2003).Wanted a National teacher Supply Policy or Education. The Right Way to meet the Highly Qualified teachers Challenge Education Policy Analysis Archive. Retrieved May 
9,2012.http://www.epaa.asu.edu/. 1(33)

Dean, C. (1994): Large Classes on the Rise. The Times Educational Supplement No. 4079. September 24.

Desimone, L, Porter, A.C., Garet M.Yoon, K.S, \& Birman, B. (2002).

Effects of Professional development on teachers' instruction: results from a three-Year longitudinal study. Educational Evaluation and Policy analysis 24(2): 81-112

Dondo, J. M. C., Krystall, A., \& Thomas, D. (1974). Report on an evaluation of the African social studies programmes. Nairobi: ASSP.

Dynneson, L. D \& Cross, R. E. (1999): Designing effective instruction for secondary Social studies. Upper Saddle River, NJ: Prentice-Hall. Inc.

Dzobo, N. K. (1972). Report of the Education Advisory Committee on the proposed new structure and content of Education for Ghana. Accra: Ghana Government Press.

Evans, R.W. (2004). The Social Studies Wars: What should we teach the children? New York: Teachers College Press.

Farrant, J.S. (1982). Principles and practice of Education. Harlow Easex: Longman Group Ltd.

Ghana Education Service (1987). Social studies syllabus for J.S.S. Accra: Curriculum Research and Development Division.

Ghana Education Service (2007). Senior High School Social Studies Draft Syllabus. Accra: Curriculum Research and Development Division

Giley, J. (1991). Demonstration and Simulation. In M.W. Galbrath (Ed). Adult learning methods. Florida: Kreiger Pub. Co. Inc.

Glass, G.V. \& Smith, M.L. (1978). Meta-analysis of research as the relationship of

class size and achievement. San Francisco: Far West laboratory for Educational Research and Development.

Goldhaber, D.B. \& Brewer, D. J. (2000). Does teacher certification matter? High school teacher certification and student achievement. Education Evaluation and Policy Analysis, 22 (2) 129-145.

Hanna, P. (1963). Revising the social studies, What is needed? Social Education 27, 190-196.

Harbison, F.H. \& Hanuscheck, J. (1991). EdururalProgramme in North East World Bank Report. Brazil; UNESCO

Harris, A. (1996). Improving Quality of Education in Africa in Quality Link, No.5 Spring 1996.

Hayford, K.B. (1992). Introduction to education in Ghana. In Abosi and Brookman Amissah (Eds). Social Studies Education, Accra: Dedlco.

Hermann, M.G., \& Preston, J.T. (1994). Presidents advisors and foreign policy: The effect of leadership style in executive arrangement political psychology. New York's. Martin Press.

Hoffman, G.L. (1980). Pupil Teacher Ratios and Academic performance. An

Experimental Analysis: Unpublished Ph.D. Thesis, University of Kansas, USA. Dissertation Abstracts on CDRom, Order No., An AC: 8102015.

Howe, G.D., \& Marshall, D. D. (1999). Citizenship education, democracy and global shifts: Re-thinking Caribbean social studies. Kingston, Jamaica:

Office of UNESCO. Representative in the Caribbean

Jordan, R., \& Powell, S (1995). Skills without Understanding. A critique of a Competency Based Model of Teacher Education. New York: Macmillan.

Kennedy, R.J. (1989). Performance measurement in non advanced further education. The use of statistics. Unpublished Ph.D. Thesis University of Lancaster, UK. British Dissertation. Abstracts No, 40-5155.

Kellough, R.D. (2003). A resource guide for teaching K-12 (4 ${ }^{\text {th }}$ Ed). Upper Saddle River, NJ, Pearson Education, Inc.

Kilpatrick, W.H. (1925): Foundations of methods: Informal talks on teaching.

New York: Macmillan.

Kim,S. J.(2006). The Influence of Class Size. Research on State and Local Education Policy. Brookings Papers on Education Policy Conference Draft Copy: University of California.

Kinder. J. C. (1965). Using Audio-Visual Material In Education. New York: Van Mostrand Co.

Knoll, M. (1997). The Project Method: its Vocational Education origin and

International Development. Journal of Industrial Teacher Education, 34 (3), 59-80.

Kraft, R.J. (1994). Teaching and Learning in Ghana. A Curriculum Textbooks Syllabus and Handbook Analysis, USDA, University of Colorado: Builder Co. Mitshel Group

Kumashiro, K. (2004). Against Common Sense: Teaching and learning towards Social Justice. New York: Bouthedge Falmer.

Laczko-Kerr. L, \& Berliner, D.C. (2002). The effectiveness of "Teach for America" and Other Under-certified teachers on Student academic achievement: A case of Harmful public policy. Education Policy Analysis Achieves, 10(37), Retrieved (data) from http://epaa.asu.edu/epaa/v/on371.

Leming, J (1991). Teacher characteristics and social studies education. In Shaver, J (Ed.). Handbook of 
research on social studies teaching and learning.

New York: Macmillan Publishing Company.

Linguist, T. (1995). Seeing The Whole Through Social Studies. Portsmouth N.H: Heinemann

Longstreet, W.S \& Shane, N.G. (1993). The social studies curriculum. in curriculum for a new millennium. Boston: Allyn and Baco Mahwah

Lucan, T. (1981). Social Studies as an integrated subject. In Melinger, H.D. (Ed.) UNESCO Handbook for the teaching of Social Studies. London: Billing and Sons Ltd.

Lyule, K. (1995). Group Teaching Methods in Kelly, L. (Ed.) The ASTD technical and skill training handbook. New York City: Mc. Graw Hill.

MacGregor, J., Cooper, J. L. Smith, K.A. \& Robinson. P. (2000). Editor's notes in MacGregor, J,.Cooper, J. L., Smith, K.A. \& Robinson, P. (Eds.)

Strategies for Energizing Large Classes: From small group to learning communities, New Directions for Teaching and Learning. San Francisco: Jossey-Boss.

MacNamara D. (1991): Subject matter knowledge and its application: problems and Possibilities or teachers educators. Journal of Teacher Education for Teaching 17 (2). 113 -128.

Mangal, S.K. \& Mangal, U (2008). Teaching of Social Studies. New Delhi Private Limited.

Manu S.Y (1993). In-Service Education for Teachers (INSET) in Ghana. Accra: Ministry of Education, Literacy House.

Martorella, P.H. (1985). Elementary Social Studies Developing Reflective Competent And Concerned Citizens. Boston: Little Brown and Company.

Martorella, P. (1994). Elementary Social Studies: Developing reflective, competent and concerned citizens: Boston: Little Brown Blandford Press.

Martorella, P. (2001). Teaching Social Studies in Middle and Secondary Schools (3 ${ }^{\text {rd }}$ ed.). Englewood, NJ: Prentice-Hall.

Matthew, J. (1989): Curriculum Exposed. London: David Fulton Publishers.

Maxim, G.W. (1997): Social Studies and the Elementary School Child.

Columby: Merril Publishing Company.

Mc William, H.O.D., \& Poh, K. (1975). The development of education in Ghana An Outline. New York: Longman Group Ltd.

McLaughlin, A (2004): Community Counts: How youth organization master for development. Washington DC: P.E.N.

Melinger, N.D. (Ed.) (1981). UNESCO Handbookfor the Teaching of Social Studies. London: Billing and Sons Ltd.

Merry-field, M. M. (1986). Social studies education and national development in selected African Nations. Unpublished Doctoral Dissertation. Indiana University.

Michaelis, J.U. (1947). Developing common goals in the social studies.

California Journal at Elementary Education, 75(1), 193.

Michaelis, J.U. (1968). Social studies for children in a democracy. Englewood Cliffs. Prentice-Hall Inc.

Michaelis, J.U. (1988). Social Studies for Children: A guide to Basic Instruction. Upper Saddle River, NJ: Perrill /Prentice-Hall. Inc.

Mombasa, (1968): EDC and CREDD. Report of a Conference of African Educators, On Social Studies, Kenya, August 19-30

Morrison, A \& Macintyre, R. (1975). Teachers and Teaching. Manchester: The Philips Press National Center for Education Statistics (NCES) 1997) America's Teachers: Profile of a Profession, 1993-94 Washington D.C. USA Department of Education Table A, 4. 15

Nacino -Brown, R.M, Oke, F.E. \& Brown, D.P (1985). Curriculum and instruction- An introduction to methods of teaching. London: McMillan

National Council for the Social Studies (1992). A vision of powerful; teaching and learning in the Social studies: Building Social Understandings and civic efficacy. Washington D.C.: Task Force on Social Studies Standards.

National Council for the Social Studies (1996). Expectations of Excellence Curriculum Standards For Social Studies: Washington, D.C.: National Council for the Social Studies.

National Council for The Social Studies (2006): NCSS. Mission Statement. Retrieved on January 27, 2012 $\mathrm{http} / / \mathrm{www}$.socialstudies.org.abt/1.

Nunnally, J.C, (1978). Psychometric Theory. McGraw-Hill Book Company

Nwadiani, M. (2000). Economic dimensions of Educational Planning in Nigeria Benin-City: Monose Amalgamates.

Orlich, D.C: Harder, R.J. Callahan, R.C. Trevisan, M.S. \& Brown, A.H. (2004). Teaching Strategies: A guide to Effective teaching $\left(9^{\text {th }}\right.$ ed.) New York: Houghton Miffin Company. 
Osborn ,A. V. (1981). Brainstorming that works your creative mind, Motorola: University Press.

Parker, W. C. (2001): Social studies in elementary education (11 ${ }^{\text {th }}$ ed.).Upper Saddle River, NJ, Merrill Prentice Hall.

Parker, C. W. \& Jarolimek, J (1997). Social studies in elementary education. Ohio: Merril an Impact of Prentice-Hall.

Preston, R. C. (1985). Teaching Social Studies in the elementary school. New York, Haly, Rinehart and Winston.

Quartey, S. M. (1984). A method book for social studies teachers. Lagos: Orit Egwa Ltd.

Quartey, S. M. (2000). The Teaching of Environmental Studies In primary Schools in Owulabi Jide (Ed.). Teaching the Ghanaian Child. Ghana: Afolabi Publishers.

Quartey, S. M. (2003): The 1987 J.S.S. social studies syllabus in Ghana:

An Analytical Content Review in International Journal of Educational Studies 2(1),

Ravitch, D. (2003). A brief history of social studies. Lemming, J. Ellenton and Porter- Magee (Eds). Where Did Social Studies Go Wrong? Washington D.C. Fordham Institute.

Rice, J. K. (2003): Teacher Quality: Understanding the effectiveness of teacher attributes. Washington D.C. EPI.

Rivkin, S. G., Hanushek, E.A. \& Kain, J.F. (2005). Teachers, schools and academic achievement Econometrica: Journal of the Econometric Society, 73(2), 417.

Risinger, C. F. (1997). Citizenship Education and The World Wide Web.

Social Education, 61(4), 223-224.

Rosenfield, B. (2004). No Subject Left Behind. Think Again. NEA Today. November, 2004. 3 (5).

Taba, H. (1962): Curriculum development theory and practice. New York:

Harcourt, Braceworld Inc.

Toss, E. W. \& Marker, P.M. (2005). If Social Studies is. I don't Want To Be Right. Theory and Research in Social Studies Education. 30, 142-151

Tyler, R. W. (1949): Basic principles of Curriculum and Instruction. Chicago. University of Chicago Press.

Ryozo, L., Miizoue, Y, Moriwake, T., \& Nagai, J. (1981): Multi-Media Instructional Materials and Social Studies. In Melinger (Ed).UNESCO Handbook for Teaching Social Studies. London: Billing and Sons.

Savage, T.V. \& Armstrong, D.G. (2000): Effective Teaching in Elementary Social Studies. Upper Saddle River, NJ: Prentice Hall. Inc.

Saxe, D. W. (1991): Social Studies in Schools: A History of The Early years. New York State University of New York Press.

Seamstorm, M. Gruber, K.J, Henke, R. McGrath, D.J. \& Cohen, B.A. (2002)

Qualifications of the Public School teachers Workforce: Prevalence of Out-ofField Teaching. Washington, D.C. NCES

Seefeldt, J, C. (2001). Social Studies for pre-school/primary child. Upper Saddle River. NJ: Prentice-Hall

Shane, H.G. \& Longstreet, W.S. (1993). The Social Studies Curriculum for a New Millennium. Boston: Allyn and Bacon Mahwah, N.J: Lawrence Erlbaum.

Shoob, S. \& Stout, C (2008): Teaching Social Studies Today. Huntington Beach, CA: Shell Education Press.

Shug, M.C. (2003). Teacher Centered Instruction. In Lemming, Ellington and Porter- Magee(Eds.) Where Did Social Studies Go Wrong? Washington D.C:

Thomas B. Fordham Institute.

Shulman, L. (1987). Those who understand knowledge growth in teaching. Educational Researcher 15 (2), 4-14. Stanley, W.S. (1991):.Teacher Competence for Social Studies in J.P. Shavel (Ed.). Handbook of Research on Social Studies Teaching and Learning. New York: Macmillan Publishing.

Tabachnic, B.R. (1991). Social Studies: Elementary School Programme. A Lewy (Ed.).The International Encyclopedia of Curriculum Oxford Pergaman Press.

Tamakloe, E.K. (1988). A survey of the teaching of Social Studies in Ghana.

African Social Studies Forum 2 (1) Nairobi: ASSP.

Tamakloe, E.K. Ed).(1994). Issues in Social Studies. Accra: Blackmask.

Tamakloe, E.K., Amadehe, F.K. \& Atta, E.T. (2005). Principles and Methods of Teaching. Accra: Super Trade Complex Ltd.

Tamakloe, E. K. (1976) The Organization of teaching and learning for the development of environmental studies in the primary schools of Ghana Strategies and implications.

Tamakloe, E.K. (2008). Issues in Social Studies Education (2 Ed). Accra: Ghana University Press.

Teddlie, C. \& Tashakkkori, A. (2003). Major Issues and Controversies In The use of Mixed Methods in the Social and Behavioral Sciences. In: C. Teddlie \& A. Tashakkori, (Eds). Handbook of Mixed Methods in Social and Behavioral Research. Thousand Oaks, CA: Sage.

Vinson, K.D. \& Ross, E.W. (2001). In Search of The Social Curriculum: Standardization, Diversity and a 
Conflict of Appearances. In W.B. Stanley (Ed.) Critical Review of Social Studies research in the $20^{\text {th }}$ Century. Greenwich, CT: Information Age

Waters T.J. \& Marzano R.J. (2006): School District leadership that Works. The Effect Of Superintendent Leadership. A Student Achievement. Mid-Continent Research for Education and Learning. July 4, 2012. http://www.etc.ca.gov/educator-prep/.../ED4005RR-superintendent.

Wenglinsky, H. (2002): How Schools Matter: The Link between teacher Classroom Practices And Students Academic Performance. Education Policy Analysis Archives 10(12)

Wesley, E.B. (1950). Teaching Social Studies In Elementary Schools. Boston: D.C. Health and Co.

Wesley, E.B. \& Wronski, S.P. (1964). Teaching Social Studies in the Classroom (5 ${ }^{\text {th }}$ Ed.). Boston D.C. Health

Whelan M. (2001). Why the study of History should be the core of Social Studies.

In. E. W. Ross (Ed). The Social Studies Curriculum; Purpose, Problem and Possibilities. Albany State University of New York press.

Wulnye, R \& Osei-Asibey, M (2011). The Impact of Service Quality in Teaching On Student's performance in the S.H.S. In Ghana. The Case of Selected Schools In Ejisu Municipal Assembly. Unpublished Master's Thesis. Lulea University of Technology. Sweden and University of Education, Winneba.

Zarrilo, A. (2000). Teaching elementary social studies: principles and Application. Upper Saddle River. Merrill Publishing Company.

Zevin, J. (2000). Social Studies for the $21^{\text {st }}$ Century: methods and Materials For Teaching, Mahwah, N.J.: Lawrence Erlbaum Associates Inc.

Zhao, Y. \& Hoge, J. D. (2005). What elementary teachers and students say about social studies. The Social Studies, 96(5), 21 